\title{
LOS PROCESOS CONSTITUYENTES EN LA HISTORIA DE CHILE: LECCIONES PARA EL PRESENTE
}

\author{
Sofia Correa Sutil \\ Universidad de Chile
}

\begin{abstract}
RESUMEN: Este artículo argumenta que el proceso constituyente que se reclama hoy en Chile debería quedar radicado en el Congreso Nacional. Este tema será abordado en perspectiva histórica para reconocer que la más exitosa experiencia chilena de cambio constitucional ocurrió en la década de 1870, con la aprobación en el Congreso de un conjunto de reformas constitucionales y electorales que transformaron esencialmente la Constitución de 1833. En contraste, la Constitución de 1925 no pudo escapar a las presiones de los militares y de Alessandri. También se argumenta que las reformas del año 2005, a pesar de su relevancia, han sido insuficientes debido a que no fueron acompañadas de la necesaria transformación del sistema electoral. Finalmente, se revisan los riesgos que conlleva una asamblea popular para redactar una nueva constitución.

Palabras ClaVe: constitución, reformas constitucionales, reformas electorales, asamblea constituyente, historia política.

RECIBIDO: diciembre 2014; ACEPTADO: enero 2015.
\end{abstract}

Sofía CoRrea Sutil. Historiadora. DPhil Oxford University (Modern History Faculty). Académica de la Facultad de Derecho de la Universidad de Chile. Entre otros libros, ha publicado Historia del siglo XX chileno. Balance paradojal (2001) (en coautoría); Con las riendas del poder: La derecha chilena en el siglo XX (2005); Ciudadanos en democracia. Fundamentos del sistema político chileno (2010). Email: scorrea@derecho.uchile.cl 


\section{CONSTITUENT PROCESSES IN CHILEAN HISTORY: LESSONS FOR TODAY}

ABSTRACT: This article argues that the constituent process that is presently being demanded in Chile should be settled in the National Congress. This topic is discussed in historical perspective in order to underline that the most successful Chilean experience in constitutional change occurred in the 1870's when a number of constitutional and electoral reforms approved by Congress essentially altered the original ethos and scope of the 1833 Constitution. On the contrary, the 1925 Constitution could not escape pressures from the military and from Alessandri. It is also argued that the constitutional reforms approved in 2005, although relevant, have been insufficient because they were not accompanied by necessary electoral reforms. Finally, the risks involved when a popular assembly is called upon to draft a new constitution are also analyzed.

KEYwords: constitution, constitutional reforms, electoral reforms, constituent assembly, political history.

RECEIVED: December 2014; ACCEPTED: January 2015.

\section{INTRODUCCIÓN}

omo es bien sabido, la demanda por reformas a la Constitución ha estado permanentemente presente en la discusión política chilena a partir del triunfo de la Concertación en el plebiscito de 1988, y se ha agudizado en los últimos meses desde que sectores académico-políticos han insistido en exigir la convocatoria a una asamblea constituyente. En este artículo se argumentará que la nueva constitución que se reclama debería ser el fruto de una profunda reforma constitucional que debería ser discutida y aprobada en el Congreso Nacional, depositario por excelencia de la soberanía nacional. Este tema será abordado en perspectiva histórica para reconocer en nuestro devenir institucional que la más exitosa experiencia de cambio constitucional ocurrió en la década de 1870, cuando el Congreso Nacional aprobó un conjunto de reformas constitucionales junto con una contundente reforma electoral, las que en conjunto transformaron esencialmente la Constitución de 1833, liberalizándola. En contraste, la Constitución de 1925, aprobada por una comisión y sometida a plebiscito, no pudo escapar de las presiones corporativas, específicamente de los militares, y del personalismo alessandrista. Argumentaremos, desde la perspectiva de la historia política, que 
las reformas a la Constitución del 80, particularmente las del año 2005, a pesar de su relevancia, han sido insuficientes porque a diferencia del proceso constituyente de la segunda mitad del siglo XIX ellas no fueron acompañadas de la necesaria transformación del sistema electoral. Finalmente, revisaremos cuáles son los riesgos que conlleva el convocar a una asamblea popular para redactar una nueva constitución política, en la medida en que con ésta se debilita al Congreso Nacional y a la vez se potencia una representación corporativa cuya legitimidad sólo podría provenir de la fuerza de presión que cada grupo de interés pudiese ostentar.

\section{LOS PROCESOS CONSTITUYENTES EN LOS INICIOS DEL SIGLO XIX}

La historia constitucional de Chile da sus primeros pasos junto con los inicios de la república, tanto así que incluso durante la dictadura de O'Higgins ${ }^{1}$ se intentó dar forma al nuevo orden institucional redactando dos constituciones $(1818,1822)$, ambas de muy corta vida. Al igual que en los ensayos constitucionales posteriores, su redacción quedó radicada en comisiones, las que después de O’Higgins emanaron de congresos constituyentes (1823, 1826 - aunque en este caso sin que se llegara a crear una nueva constitución - y 1828), pudiendo eso sí reconocerse la mano de sus principales redactores (Rodríguez Aldea en 1822, Juan Egaña en 1823, José Joaquín de Mora en 1828). Además, en este período inicial, para legitimar cada nueva carta se recurría a plebiscitos o a consultas a las provincias, inicialmente a los cabildos y luego a las asambleas provinciales, todas ellas instancias controladas por elites locales. Este proceso de ensayos para llegar a redactar una constitución para la naciente república llegó a su madurez con la creación de la Constitución de 1828, la cual serviría de molde para las subsecuentes constituciones de 1833 y 1925, consideradas reformas cada cual de la que la precede. No obstante, al igual que sus antecesoras, la Constitu-

${ }^{1}$ El concepto de dictadura aplicado al período de O’Higgins ha sido utilizado desde la historiografía clásica del siglo XIX (por ejemplo, Miguel Luis Amunátegui, La dictadura de O'Higgins, 1853) y por historiadores contemporáneos. Para una discusión al respecto, véase Alfredo Jocelyn-Holt Letelier, La independencia de Chile. Tradición, modernización y mito (Santiago: Debolsillo, 2009), 292-300. 
ción de 1828 es de muy corta vida, no alcanza a durar dos años, a pesar de haber sido ampliamente aceptada. La crisis constitucional se genera en 1829 a partir de opuestas interpretaciones de la Constitución recién promulgada, con ocasión de la elección del vicepresidente de la república, dado que la Constitución había entregado al Congreso la decisión final entre los candidatos más votados. La crisis política, que derivó en la rebelión de las asambleas provinciales de Maule a Concepción apoyada por el ejército del sur, se resolvía en el campo de batalla en abril de $1830 .^{2}$

Luego del triunfo de los insurrectos, desde el Cabildo de Santiago y en el Senado se planteó la necesidad de reformar la Constitución de 1828. Como la rebelión se había justificado en la defensa de la Constitución, la que surgía en 1833 no podía sino iniciarse como una reforma de la de 1828. Para ello, el Senado convocó en 1831 a una convención compuesta por 16 diputados y 20 ciudadanos probos e ilustrados que podían también ser, y en su mayoría lo fueron, miembros del Congreso (14 de los 20). Todos los integrantes de la convención fueron elegidos por el Congreso pleno, aunque, dado el contexto político, el ministro del Interior intervino enviando la lista de los que debían ser electos. La convención, que algunos llaman asamblea constituyente, nombró a su vez una comisión de tres miembros para afinar las divergencias que se habían presentado en su seno, quienes decidieron que la reforma de la Constitución del 28 debía partir con la elaboración de un proyecto por parte de una comisión compuesta por siete miembros de la convención. Así se hizo y en octubre de 1832, la convención iniciaba la discusión del proyecto preparado por dicha comisión. Luego de la aprobación por el Congreso, la nueva carta fue promulgada a mediados de $1833 .^{3}$ Es

${ }^{2}$ Fernando Campos Harriet, Historia constitucional de Chile (Santiago: Editorial Jurídica de Chile, 1983), 338-356; Sergio Carrasco Delgado, Génesis y vigencia de los textos constitucionales chilenos (Santiago: Editorial Jurídica de Chile, 2002); Julio Heise, Años de formación y aprendizaje políticos 1810-1833 (Santiago: Editorial Universitaria, 1978); Jocelyn-Holt, La independencia de Chile, capítulo 8; Pablo Ruiz-Tagle, "El constitucionalismo chileno: entre el autoritarismo y la democracia", en La República en Chile. Teoría y práctica del constitucionalismo republicano, de los autores Renato Cristi y Pablo Ruiz-Tagle (Santiago: LOM, 2006), 82-93.

3 Campos Harriet, Historia constitucional, 356-366; Carrasco Delgado, Génesis y vigencia 106-115; Eric Eduardo Palma González, Historia del derecho chileno (1808-1924) (Santiago: Facultad de Derecho, Universidad de Chile, sin fecha), 234-237. 
decir, radicada en un núcleo muy reducido surgido desde el Congreso Nacional, esto es en una comisión de siete integrantes de una convención de 36 miembros, fue desde donde se redactó la Constitución de 1833, cuya aprobación quedó en manos del Congreso Nacional, en ese entonces conformado a partir de las listas electorales preparadas por el ministro del Interior.

Es por todos sabido que la Constitución de 1833 concentró el poder político en el ejecutivo, entendiendo por tal el Presidente de la República y los ministros que con él gobernaban. ${ }^{4}$ Por ejemplo, le otorgaba la amplísima facultad de nombrar a todos los magistrados y velar por la conducta de los jueces. Por otra parte, controlando la totalidad del proceso electoral, el ejecutivo podía configurar la composición de las Cámaras con personalidades afines o bien consecuentes. A su vez, el Congreso podía otorgarle facultades extraordinarias, como de hecho lo hacía continuamente, que suspendían las garantías individuales permitiéndole al gobierno reprimir cualquier oposición, y que incluso implicaron delegación de la potestad legislativa (como ocurrió en 1837). Adicionalmente, la Constitución le otorgaba al Presidente poder de veto absoluto a la legislación aprobada en el Congreso, la que no podía volver a ponerse en discusión en la misma legislatura. En esas condiciones, el poder político del ejecutivo era

${ }^{4}$ Los ministros de Estado (inicialmente sólo tres: Interior y Relaciones Exteriores; Guerra y Marina; Hacienda) tenían enorme poder, en la medida en que todos los proyectos de ley debían llevar la firma del ministro correspondiente. Pero, sobre todo, era el ministro del Interior la figura más poderosa del ejecutivo puesto que en su despacho se configuraban las listas oficiales de candidatos al Congreso, todos los cuales por cierto resultaban electos. En cuanto al Presidente de la República, si bien tenía la facultad de nombrar y remover a voluntad a los ministros de Estado, pensamos que mientras ese cargo lo ejerció el comandante del Ejército del Sur, es decir hasta 1850, el Presidente seguía ejerciendo el rol que para el anterior período ha visualizado Alfredo Jocelyn-Holt en La independencia de Chile, a saber, el de árbitro entre las principales fracciones civiles. Tal habría sido, por ejemplo, el papel jugado por Manuel Bulnes ante el conflicto entre Manuel Camilo Vial y Manuel Montt que amenazaba romper la unidad de las fuerzas de gobierno, en vísperas de una próxima elección presidencial. Incluso tan tardíamente como 1867, con ocasión de las elecciones parlamentarias de ese año, el Presidente Pérez debió ejercer el rol de mediador entre el ministro del Interior y el Partido Conservador que integraba la alianza gobernante, con respecto a la incorporación de Abdón Cifuentes en la lista oficial de candidatos por Rancagua. 
imbatible a lo cual hay que agregar que era casi imposible reformar la Constitución, pues para ello se requerían dos legislaturas consecutivas. $^{5}$

¿Cómo pudo entonces la Constitución de 1833 servir de soporte al parlamentarismo que caracterizó a Chile en el cambio de siglo?

\section{MUTACIÓN CONSTITUCIONAL VÍA REFORMA}

La ruptura del férreo control presidencial fue posible como consecuencia del proceso político que produjo el quiebre de las fuerzas de gobierno entre, por una parte, quienes defendían una posición ultramontana que implicaba la autonomía de la jerarquía eclesiástica con respecto al gobierno, y quienes, por otra, defendían las prerrogativas que el derecho de patronato otorgaba al Estado frente a la Iglesia, a raíz del dramático episodio conocido como "la cuestión del sacristán", en 1856. Tras una breve guerra civil (1859), las fuerzas en control del gobierno, Montt y Varas en particular, aunque triunfantes en el campo de batalla, comprendieron que era tiempo de ceder y abrir cauce a una mayor pluralidad política. Ello fue lo que dio origen a una etapa de grandes reformas, tanto de la Constitución como de las leyes electorales, y a nuevas prácticas políticas a partir de la década de 1860. En efecto, desde la elección del montt-varista José Joaquín Pérez en 1861 el gobierno dejó de solicitar al Congreso facultades extraordinarias y nunca más se declaró estado de sitio en alguna parte del territorio nacional. ${ }^{6}$ Sistemáticamente, el Congreso comenzó a ejercer facultades fiscalizadoras a través de la práctica de interpelar a los ministros de Estado. ${ }^{7}$ En cuanto a las normas constitucionales que concentraban el

${ }^{5}$ Campos Harriet, Historia constitucional; Julio Heise, Historia de Chile. El periodo parlamentario 1861-1925. Tomo 1. Fundamentos histórico-culturales del parlamentarismo chileno (Santiago: Editorial Andrés Bello, 1974); Germán Urzúa Valenzuela, Historia política de Chile y su evolución electoral (desde 1810 a 1992) (Santiago: Editorial Jurídica de Chile, 1992).

${ }^{6}$ Sobre la moderación política en el siglo XIX, véase Alfredo Jocelyn-Holt, "El liberalismo moderado chileno. Siglo XIX", Estudios Públicos 69 (1998). Disponible en http://www.cepchile.cl/dms/archivo_902_313/rev69_jocelynholt.pdf/

${ }^{7}$ Heise, Historia de Chile, quien argumenta sobre el desarrollo y la importancia de las prácticas parlamentarias. 
poder en el Presidente de la República, éstas fueron desmanteladas por sucesivas reformas. ${ }^{8}$

Así, una ley de 1867 aprueba la reforma de 19 artículos de la Constitución, los que debían ser revisados en la siguiente legislatura, electa en 1870 (de allí el título del famoso libro de los hermanos Arteaga Alemparte, Los constituyentes de 1870). Si bien esta legislatura sólo aprobó la reforma del período presidencial, prohibiendo la reelección inmediata (agosto de 1871), a la vez declaró reformables otros tantos artículos de la Constitución, cuestión que requería de la aprobación de la siguiente legislatura electa en $1873 .{ }^{9}$ Así fue como en 1873-74 se aprobaron las más importantes reformas constitucionales que cambiaron el carácter fuertemente presidencialista de la Constitución de $1833,{ }^{10}$ generando una "mutación constitucional" en palabras del constitucionalista Pablo Ruiz-Tagle. ${ }^{11}$

En efecto, la segunda enmienda constitucional, de septiembre de 1873, rebajó los quórum necesarios para que las Cámaras pudiesen sesionar, que eran de mayoría absoluta de sus miembros, permitiendo al Senado sesionar con una tercera parte y a la Cámara de Diputados con una cuarta parte de sus integrantes. ${ }^{12}$ Un año más tarde, una ley de reforma constitucional reconocía los derechos de libertad de reunión, de asociación - fundamentales para la actividad política y el funcionamiento de los incipientes partidos políticos- y de enseñanza, ${ }^{13}$ tan cara a los ultramontanos convertidos en Partido Conservador. En esa misma fecha, agos-

${ }^{8}$ Intentos anteriores de reformar la Constitución no tuvieron éxito. Por ejemplo, en 1849 Lastarria propuso una reforma constitucional que restringiera las facultades extraordinarias y las declaraciones del estado de sitio, junto a una reforma electoral; y en 1850 Federico Errázuriz Zañartu propuso, en la Cámara, un proyecto de reforma muy amplia, que reducía las facultades presidenciales, la que no tuvo suficiente respaldo. En 1858, Lastarria y Santa María propusieron nuevamente en la Cámara de Diputados una reforma electoral; en 1860 el diputado Melchor de Santiago Concha presentó una reforma que no llegó a discutirse en la Cámara. Véase Ricardo Donoso, Las ideas politicas en Chile (Buenos Aires: Eudeba, 1975), 376-377, 380-384.

${ }^{9}$ Heise, Historia de Chile, 38-39; Donoso, ibidem, 385-387. En 1871 el diputado Manuel Antonio Matta presentó a la Cámara un proyecto de reforma constitucional que planteaba cambios radicales. Véase del mismo Donoso, ibidem, 389-390.

${ }^{10}$ Campos Harriet, Historia constitucional; Heise, ibídem.

${ }^{11}$ Ruiz-Tagle, "El constitucionalismo chileno", 106.

${ }^{12}$ Heise, Historia de Chile, 39; Donoso, Las ideas politicas, 391.

${ }^{13}$ Heise, ibídem, 39-40; Donoso, ibídem, 391-392. 
to de 1874 , se establecieron diversas incompatibilidades para ejercer los cargos de diputado y senador, de modo de separar los poderes públicos y, por otra parte, evitar la influencia del clero regular en las Cámaras; eso sí, siguió siendo compatible el cargo de parlamentario con el de ministro de Estado, lo que facilitó el giro hacia un régimen de tipo parlamentario. A juicio de Julio Heise, "esta reforma quebrantó seriamente el autoritarismo presidencial". A la vez, también se reformó la elección de senadores, que de acuerdo al sistema mayoritario se elegían en lista completa, lo que implicaba que ningún senador de oposición podía ser electo. La reforma introdujo la votación directa por provincias, aumentó el número de senadores y redujo su período de nueve a seis años. ${ }^{14}$ Dos meses más tarde se aprobaban nuevas reformas: se limitaron las facultades extraordinarias, quedando explícitamente prohibida la delegación de la potestad legislativa, y se prohibió que durante el estado de sitio quedara suspendida la vigencia de la Constitución. Además se cambió la composición y atribuciones de la Comisión Conservadora, institución que funcionaba durante el receso del Congreso. A los siete senadores que la integraban se agregaron siete diputados. Se la facultó para velar por el cumplimiento de la Constitución y la protección de las libertades públicas, se le otorgó la supervigilancia sobre la administración pública, y se la facultó para poder solicitar al Presidente que convocara al Congreso a sesiones extraordinarias. También en esta ocasión se limitaron las facultades presidenciales sobre los jueces; se cambió la composición y atribuciones del Consejo de Estado, agregándose tres representantes del Senado y tres de la Cámara de Diputados a los cuatro miembros designados por el Presidente y éste sólo podría remover a los consejeros de Estado de su elección. Por último, con esta enmienda de agosto de 1874, también se facilitó la acusación constitucional a los ministros de Estado por parte de la Cámara de Diputados. ${ }^{15}$

De modo que con esta serie de reformas que empoderaban al Congreso Nacional y debilitaban la fortaleza inexpugnable del ejecutivo se había producido la "mutación constitucional".

Posteriormente se hicieron pocas reformas adicionales. En enero de 1882 se aprobó, para ser revisada en la siguiente legislatura, la reforma

${ }^{14}$ Heise, Historia de Chile, 40-42; Donoso, Las ideas políticas, 402.

${ }^{15}$ Heise, ibídem, 43-46. Simultáneamente se dejaba atrás la legislación española promulgándose en 1874 el Código Penal; el mismo año, el Código de Minería; y en 1875, la Ley de Organización y Atribuciones de los Tribunales. Carrasco Delgado, Génesis y vigencia, 134. 
constitucional que permitía que ésta se originase en cualquiera de las dos Cámaras, que el ejecutivo no pudiera vetarla sino sólo introducir modificaciones, y que, una vez aprobada y publicada, la reforma sólo tuviese que ser ratificada por el Congreso siguiente. Además se aprobó que las reformas constitucionales se pudieran discutir en las legislaturas extraordinarias, aunque el ejecutivo no las hubiese incluido en la convocatoria. En 1888, se confirmaron las reformas constitucionales relativas al sistema electoral, entre éstas la supresión de los requisitos censitarios; en 1891, se ratificó la autorización a la Comisión Conservadora para convocar al Congreso a sesiones extraordinarias; en 1892, se ratificaron las reformas sobre incompatibilidades parlamentarias respecto, por ejemplo, de empleos públicos retribuidos, de magistrados y jueces, intendentes y gobernadores; en 1893, sobre la insistencia de las Cámaras al veto presidencial; en 1917, sobre elecciones. Por último, en 1924 se aprobó una reforma constitucional principalmente referida a la remuneración a los parlamentarios (dieta) y a la capacidad del Presidente para disolver la Cámara una vez durante su mandato para llamar a nuevas elecciones, reforma que debió haber sido ratificada en la siguiente legislatura, lo cual, como bien sabemos, lo impide un golpe de Estado. ${ }^{16}$

\section{REFORMAS ELECTORALES EN EL SIGLO XIX}

Señalábamos que las reformas constitucionales de 1874 que produjeron la mutación constitucional de la Carta del 33 fueron acompañadas de una profunda reforma electoral, que permitió materializar en la práctica política el desafío al autoritarismo presidencial que a nivel normativo habían logrado desmantelar las reformas constitucionales. ${ }^{17}$

${ }^{16}$ Heise, ibídem, 46; Luis Valencia Avaria (compilador), Anales de la República. Tomos I y II actualizados (Santiago: Editorial Andrés Bello, 1986), 205-213.

${ }^{17}$ Sobre la importancia de la institucionalidad electoral en la historia política chilena, véase Paul Drake, Between tyranny and anarchy. A history of democracy in Latin America, 1800-2006 (Stanford: Stanford University Press, 2009), y en particular sobre las reformas electorales de 1874: 114-116. Sobre las características del sistema electoral bajo la Constitución de 1833 y particularmente sobre la importancia de la reforma de 1874, véase J. Samuel Valenzuela, Democratización vía reforma: La expansión del sufragio en Chile (Buenos Aires: Ediciones del IDES, 1985). También Julio Heise, El periodo parlamentario 1861-1925. Tomo II. Democracia y gobierno representativo en el periodo parlamentario (Santiago: Editorial Universitaria, 1982). 
En efecto, la legislación electoral estuvo siempre estrechamente vinculada a la Constitución. ${ }^{18}$ Por lo tanto, una vez promulgada la Constitución de 1833, a fines de ese año, fue aprobada la ley de elecciones que daba forma a la representación política por medio del voto masculino adulto, letrado y censitario. ${ }^{19}$ Cada diez años una ley debía fijar los requisitos censitarios, variables según las provincias, para ponerlos al día de acuerdo a las nuevas realidades del decenio. Todo el proceso electoral, desde la inscripción del votante al escrutinio de los votos, quedaba en manos de las municipalidades, las cuales eran presididas por el intendente o el gobernador según si se trataba de cabeceras provinciales o departamentales, quienes tenían la facultad de vetar las decisiones del municipio. ${ }^{20}$ En los hechos, el proceso electoral quedaba enteramente en manos del ejecutivo y, como ya decíamos, las listas de

18 Sobre la representación política en los inicios de la república, véase Donoso, Las ideas politicas, capítulo X; Paulo Recabal, "Para entender la realidad electoral en los albores de la República: ciudadanía y representación en el primer Congreso Nacional", en Seminario Estudios de la República, http://www. estudiosdelarepublica.cl/plugins/news/images/17_paulo_recabal congreso_pdf. pdf/

19 Tenían derecho a voto los hombres mayores de 21 años si eran casados y 25 años si eran solteros, que supieran leer y escribir y que tuviesen una determinada renta o propiedad que debía fijarse por ley cada diez años. El requisito de saber leer y escribir quedó suspendido hasta 1840 en el artículo primero de las disposiciones transitorias de la Constitución de 1833; en 1842 se estimó que quienes ya habían ejercido sus derechos ciudadanos podrían seguir haciéndolo aunque no supiesen leer y escribir. Véase Valencia Avaria, Anales de la República.

Quedaron excluidos del derecho a voto "los que por imposibilidad física o moral no gocen de su razón; los sirvientes domésticos; los deudores al fisco constituidos en mora; los condenados a penas aflictivas o infamantes que no manifiesten decreto de rehabilitación; los fallidos presentados como tales a los tribunales; los individuos del clero regular [exclusión suprimida con la reforma electoral de 1861]; los soldados, cabos y sargentos del ejército permanente; los jornaleros y los peones gañanes" (Artículo 16 del "Reglamento de elecciones" de 1833). El texto del reglamento electoral de 1833 se encuentra en Seminario Estudios de la República, http:// www.estudiosdelarepublica.cl/plugins/news/images/7_paulo_recabal__presentaciun_reglamento_electoral_de_1833_pdf.pdf/

${ }^{20}$ Antes de la ley de comuna autónoma de 1892 las municipalidades estaban situadas en las cabeceras de los departamentos y en la cabecera provincial. Eran por tanto siempre urbanas. En vísperas de la aprobación de la ley de comuna autónoma había 72 municipalidades en el país, de acuerdo a Heise, El período parlamentario, 251. 
candidatos oficiales elaboradas por el ministro del Interior tenían asegurada la elección. Ello era particularmente claro en el caso de la elección de senadores, que, hasta 1874 , se votaban en lista completa para todo el territorio nacional y por voto indirecto. El autoritarismo presidencial era imbatible en la medida en que por la vía electoral el ejecutivo controlaba la composición del Congreso. ${ }^{21}$

Para evitar que el ejecutivo dominara el proceso electoral era necesario quitarle el control de éste a las municipalidades. La primera reforma en tal sentido es de $1869,{ }^{22}$ cuando se crea la Junta de Mayores Contribuyentes como instancia revisora de los reclamos que se suscitaran en relación a las inscripciones electorales (llamadas calificaciones porque la inscripción constaba en una boleta de calificación que portaba el votante), las que debían realizarse antes de cada período electoral y que estaban en manos de las municipalidades. Las Juntas de Mayores Contribuyentes quedaron conformadas por seis miembros elegidos al azar por la municipalidad de entre los cuarenta mayores contribuyentes del departamento. Era, sin duda, una reforma tímida, pero iniciaba un proceso sin retorno. La reforma electoral de 1869 contenía también otras disposiciones de importancia, tales como reducir la votación a un solo día. 23

Al igual que ocurriera con las reformas constitucionales, la más importante reforma electoral se aprobó en 1874, con ocasión de la discusión parlamentaria sobre los montos que se fijarían a los requisitos censitarios que debían definirse por ley para regir durante todo el decenio próximo. Al respecto, se estableció la presunción de derecho de que todos aquellos que supiesen leer y escribir tendrían los requisitos censi-

${ }^{21}$ Heise, El período parlamentario, capítulo preliminar; Donoso, Las ideas políticas, capítulo $\mathrm{X}$.

${ }^{22}$ Señala Julio Heise: "El 12 de noviembre de 1842 se promulgó la primera modificación a la Ley electoral del año 1833 bajo el título Suplemento a la Ley de Elecciones. Esta reforma no significó avance alguno; en cierto sentido reafirmó el control legal del Ejecutivo sobre las diversas etapas del proceso electoral [...]. En las postrimerías del decenio de Montt — en septiembre de 1861— se aprobó una segunda reforma que pretendió perfeccionar algunos aspectos del régimen electoral, pero siempre dentro de una estricta dependencia del Ejecutivo y sobre la base del sistema censitario establecido en la Constitución." El período parlamentario, 19-20.

${ }^{23}$ Heise, ibídem, 50-51. 
tarios para votar. ${ }^{24}$ Por lo demás, los montos requeridos para ejercer el derecho a voto eran por entonces muy bajos. Sabemos que hacia 1870 tales requisitos los cumplían, por ejemplo, el portero de la Presidencia de la República, el de Aduanas de Valparaíso, el de la Corte de Apelaciones de Concepción y el de Tesorería y Aduanas del departamento de Valdivia; también, por ejemplo, el carpintero de la Casa de Moneda y el maestro zapatero de la Casa de la Providencia; el auxiliar de telegrafista de La Serena, el celador de la oficina de telégrafo en Valparaíso y el cartero ambulante de Valparaíso. ${ }^{25}$ A pesar de que los requisitos censitarios eran bajos, el hecho de que se les suprimiera tuvo enorme importancia pues restó atribuciones a las municipalidades, que eran las que certificaban que los potenciales electores cumpliesen con las condiciones de renta o propiedad necesarias para poder votar, a no ser que fuesen empleados públicos cuyas remuneraciones estaban fijadas por ley. La consecuencia inmediata de esta reforma fue un aumento significativo del universo electoral, que más que se triplicó, desde 25.981 votantes en 1873 a 80.346 en 1876, según lo ha hecho notar J. Samuel Valenzuela, quien además destaca el hecho de que la mayoría de los nuevos votantes aparecen en los registros como agricultores. ${ }^{26}$ Es decir, lo que aumenta significativamente es el voto rural, y bien sabemos que eran los grandes hacendados quienes controlaban la sociedad rural en

${ }^{24}$ Para suprimir los requisitos censitarios se requería de una reforma constitucional, y por tanto de dos legislaturas. La idea de recurrir a una presunción de derecho para suprimir los requisitos censitarios fue de Zorobabel Rodríguez, diputado del Partido Conservador, aunque ya se había planteado con anterioridad por el diputado Pedro Félix Vicuña, en 1864, y por los diputados Antonio Varas y Domingo Santa María en la siguiente legislatura (Heise, El periodo parlamentario, 53). Una reforma constitucional en 1888 suprime definitivamente los requisitos censitarios. Véase J. Samuel Valenzuela, "Hacia la formación de instituciones democráticas: prácticas electorales en Chile durante el siglo XIX", Estudios Públicos 66 (1997), http://www.cepchile.cl/dms/archivo_1158_697/rev66_valenzuela.pdf/

${ }^{25} \mathrm{La}$ ley electoral de 1864 que fija los requisitos censitarios en Heise, El período parlamentario, 52. Compárese con los sueldos de los empleados públicos consignados en el Anuario estadístico de la República de Chile correspondiente a los años 1870-1871. De acuerdo con Heise, ibídem: "De la población nacional que por aquellos años llegaba a 2.000.000 de habitantes, por lo menos el 10\% —esto es 200.000 - reunían los requisitos legales para tener la calidad de ciudadano elector. Sin embargo, en la práctica éstos apenas sobrepasaban los 10.000".

${ }^{26}$ S. Valenzuela, "Instituciones democráticas". 
su conjunto. ${ }^{27}$ De modo pues que estamos ante una significativa disminución de la capacidad de manejo electoral del ejecutivo, y un mayor poder electoral de los dirigentes que controlaban los partidos políticos y que buscaban reflejar su dominio social en el Congreso Nacional sin someterse a las maniobras presidenciales.

La posibilidad de control electoral del ejecutivo se vio también afectada por otras reformas electorales de ese mismo año 1874. El Congreso aprobó el voto acumulativo ${ }^{28}$ en todas las elecciones (reforma defendida con ardor por los parlamentarios del Partido Conservador) ${ }^{29}$; el Presidente quiso vetarlo, pero para ello tuvo que negociar con los dirigentes del Partido Radical, a consecuencia de lo cual el voto acumulativo quedó limitado a las elecciones de diputados y los radicales entraron al gobierno. ${ }^{30}$ Con esta reforma las minorías electorales pudieron elegir parlamentarios a la Cámara Baja. Además, como ya señaláramos, una enmienda constitucional reformó la elección de senadores, la cual pasó de una elección por lista completa para todo el país a ser elegidos por provincias en proporción a su población, y por voto directo.

Adicionalmente, con el propósito de restar poder electoral a las municipalidades, que eran controladas por el ejecutivo, se ampliaron las atribuciones de las Juntas de Mayores Contribuyentes, que habían sido creadas, como vimos, algunos años antes. Se las convirtió en Juntas Calificadoras, con lo cual se las dotó de la función de calificar al elector en el proceso de inscripción electoral, y fueron ellas las que conformaron

${ }^{27}$ Sobre la sociedad rural chilena, véase, por ejemplo, el clásico libro de Arnold Bauer, La sociedad rural chilena. Desde la conquista española a nuestros días (Santiago: Editorial Andrés Bello, 1994), y el voluminoso estudio de José Bengoa, Historia social de la agricultura chilena, publicada en dos volúmenes: Tomo I: El poder y la subordinación. Acerca del origen rural del poder y la subordinación en Chile (Santiago: Ediciones Sur, 1988) y Tomo II: Haciendas y campesinos (Santiago: Ediciones Sur, 1990).

${ }^{28}$ El voto acumulativo significa que cada votante tiene tantos votos como cargos a elegir, y que puede acumularlos en un solo candidato. Véase Heise, El período parlamentario, 54-56.

${ }^{29}$ Campos Harriet, Historia constitucional, 379.

${ }^{30} \mathrm{El}$ voto acumulativo se extendió a las elecciones de regidores, de senadores y de electores de Presidente de la República con la ley electoral de 1890. Sobre la ley electoral de 1890 y las otras reformas que contiene, véase Heise, El período parlamentario, 91-92; y J. Samuel Valenzuela, "La ley electoral de 1890 y la democratización del régimen político chileno", Estudios Públicos 71 (1998), http:// www.cepchile.cl/dms/archivo_1152_730/rev71_valenzuela.pdf/ 
las Juntas (o mesas) Receptoras de Sufragios. Se prohibió que los empleados de nombramiento presidencial integraran las Juntas de Mayores Contribuyentes. ${ }^{31}$

Campos Harriet ha hecho notar que a partir de 1874 los mayores contribuyentes se configuraban con quienes pagaban mayor contribución agrícola, de patente industrial o de alumbrado y sereno, "tomadas colectivamente". ${ }^{32}$ Como los mayores contribuyentes se definían por departamentos, las diferencias a lo largo del país eran enormes, y en aquellas zonas más pobres los montos de las contribuciones eran muy bajos. Por ejemplo, en 1877-1878, en el departamento de Quinchao, provincia de Chiloé, había entre los mayores contribuyentes algunos que pagaban sólo $\$ 1.50$, y en el departamento de Imperial, provincia de Arauco, los había con contribuciones de sólo $\$ 0.25$, mientras que en el departamento de San Fernando, provincia de Colchagua, los mayores contribuyentes aparecen con montos desde $\$ 2160.00$, y el departamento de Limache, provincia de Valparaíso, ostenta en esos años las cifras más altas del país, con mayores contribuyentes de $\$ 3096.00$. Además, dentro de un mismo departamento las cifras tenían fuertes variaciones. Así, por ejemplo, en el departamento de Concepción los mayores contribuyentes pagaban desde $\$ 65.80$ hasta $\$ 269.20$; en el departamento de Talca hay mayores contribuyentes que pagan $\$ 405.50$ mientras otros aparecen con \$1418.70; y el mayor contraste se da en el departamento de Limache, con una diferencia entre los mayores contribuyentes desde $\$ 3096.00$ a $\$ 38.84 .^{33}$

A consecuencia de las reformas electorales de 1874, el ejecutivo careció de los instrumentos legales para ejercer la intervención electoral, de modo que esta práctica, que continuó hasta la Guerra Civil de 1891, tuvo que asentarse en la fuerza y en la violencia. Tal es la descripción que hace Julio Heise de las elecciones de 1885, bajo la presidencia de Domingo Santa María: "Los agentes del ejecutivo inscribían y hacían sufragar con nombres distintos más de diez veces a cada policía. Con ellos se organizaban también turbas para asaltar mesas,

${ }^{31}$ Heise, El periodo parlamentario, 51; S. Valenzuela, "La ley electoral”. Después de la Guerra Civil, las reformas electorales de 1893-1894 ampliaron las atribuciones de las Juntas de Mayores Contribuyentes. Heise, ibídem, 111-112.

${ }^{32}$ Campos Harriet, Historia constitucional, 379.

33 Anuario estadístico de la República de Chile correspondiente a los años 1877-1878, 137 y siguientes. 
secuestrar mayores contribuyentes y vocales de la oposición, y robar registros y urnas. [...] En los departamentos de Talca, Curicó, Putaendo, Santiago, Cachapoal y Puchacay el gobierno organizó un asalto masivo a las mesas receptoras de sufragios. [...] En la Cámara, la mayoría gobiernista completó la labor interventora practicando una calificación con sentido puramente político." ${ }^{34}$ El Presidente Santa María lo reconocería abiertamente en la ya famosa carta que le escribiera a su biógrafo Pedro Pablo Figueroa, reproducida por los historiadores Francisco Antonio Encina y Mario Góngora: "Se me ha llamado interventor. Lo soy. Pertenezco a la vieja escuela y si participo de la intervención es porque quiero un parlamento eficiente, disciplinado, que colabore con los afanes de bien público del gobierno." 35 Sólo después de la Guerra Civil de 1891 la intervención electoral del ejecutivo se terminó.

Por otra parte, como consecuencia de estas reformas de 1874, particularmente con el voto acumulativo para las elecciones de diputados, los partidos se vieron obligados a realizar sofisticados cálculos electorales en cada localidad para distribuir adecuadamente los votos entre sus candidatos, y tuvieron que contar con agentes partidistas distribuidos en todo el país, lo que los enraizó localmente y los fortaleció. ${ }^{36}$

Así, las reformas constitucionales y electorales, particularmente las de 1874 , en conjunto con las prácticas parlamentarias ${ }^{37}$ asentadas en la década de 1860, transformaron el régimen presidencial autoritario consagrado en la Constitución de 1833 en un régimen parlamentario con preeminencia del Congreso. Sea que el parlamentarismo existiera en la conciencia política antes de 1891, que tal ha sido el argumento del historiador Julio Heise González, es indudable que el triunfo del Congreso en la Guerra Civil de 1891 clausura definitivamente las prácticas autoritarias del presidencialismo. Hasta la llegada de Arturo Alessandri a la Presidencia de la República en 1920, la que da inicio a un nuevo ciclo político y constitucional en Chile.

${ }^{34}$ Heise, El periodo parlamentario, 71-72.

${ }^{35}$ Citado por Mario Góngora, Ensayo histórico sobre la noción de Estado en Chile en los siglos XIX y XX (Santiago: Editorial Universitaria, 1986), 59.

${ }^{36}$ S. Valenzuela, "Instituciones democráticas."; S. Valenzuela, "La ley electoral"; Sofía Correa Sutil, "El Congreso durante el parlamentarismo. Revisión crítica del centralismo presidencial", Hemiciclo 4 (2011), http://www.academiaparlamentaria.cl/Hemiciclo/revistahemiciclo_N4.pdf/

${ }^{37}$ Principalmente las interpelaciones y votos de censura contra los ministros de Estado. Véase Heise, Historia de Chile, 61-67. 


\section{EL PROCESO CONSTITUYENTE DE 1925}

Cuando se promulgó la nueva constitución presidencialista en septiembre de 1925, hacía ya tiempo que el proceso político se había salido del cauce constitucional que enmarcaba la Constitución de 1833 con su modalidad de parlamentarismo a la chilena. ${ }^{38}$ Por de pronto, el Presidente Arturo Alessandri desde comienzos de su período había desplegado una retórica crítica del Congreso Nacional - apuntando particularmente contra el Senado-, había convocado a mítines populares en su apoyo y, no menor, había recorrido las unidades militares del país para quejarse del entorpecimiento del Congreso a su programa de gobierno, insistiendo en la conveniencia de un régimen presidencial. Además, contradiciendo prácticas políticas de larga data, desconoció las censuras parlamentarias a sus ministros, insistió en mantener gabinetes que no contaban con apoyo parlamentario, nombró a militares como ministros de Estado, intervino personalmente en los debates parlamentarios, alentó disputas entre las Cámaras, publicó en la prensa manifiestos a favor del régimen presidencial, y movilizó al pueblo para amedrentar a sus opositores. Con ocasión de las elecciones parlamentarias de 1924 recorrió el país haciendo campaña a favor de la Alianza Liberal, acompañado por oficiales de ejército. Nada de extraño entonces que, en septiembre de 1924, un grupo de militares hiciera sonar sus sables en las graderías del Congreso, en rechazo a que en el hemiciclo se discutiera una ley para crear la dieta parlamentaria, iniciativa democratizadora del Congreso, dando inicio así a una serie de acontecimientos que terminarían con una junta militar en el poder, el Presidente en el exilio y el Congreso clausurado. ${ }^{39}$

Entre tanto, en la década de 1920 la crisis política se expresó también en un álgido debate político y constitucional. En ese contexto, sectores más bien ajenos a los partidos asentados en el Congreso apostaron por una nueva constitución para Chile, de carácter socialista, corporativista y federal. Así, Luis Emilio Recabarren, fundador del Partido Comunista, publicaba en 1921 en Antofagasta su proyecto de una

${ }^{38}$ Existe consenso entre cientistas políticos y constitucionalistas que se trata de una forma de gobierno muy particular, alejada de los moldes del parlamentarismo europeo de fin de siglo.

39 Sofía Correa Sutil et al., Historia del siglo XX chileno. Balance paradojal (Santiago: Sudamericana, 2001), capítulo IV; Heise, Historia de Chile, 434-455. 
constitución que permitiría organizar la República Federal y Socialista de Chile. ${ }^{40}$ También el historiador Gabriel Salazar ha destacado la existencia de una Asamblea Constituyente de Asalariados e Intelectuales, la que reuniendo a representantes gremiales de obreros, empleados, estudiantes, profesionales e intelectuales, en marzo de 1925, en el Teatro Municipal, habría acordado las bases para una nueva constitución. ${ }^{41}$ Dichas bases tuvieron un carácter federal y corporativista con una propuesta de cámaras funcionales en las que la ciudadanía estaría representada a través de sus organizaciones gremiales. ${ }^{42}$

Por otra parte, en todos los mensajes presidenciales con que inauguraba la legislatura ordinaria, Alessandri había insistido en la necesidad de reformar la Constitución para restar atribuciones políticas y fiscalizadoras al Congreso. A su vez, en los primeros meses de 1924, tras un acuerdo entre los partidos de gobierno y de oposición, el Congreso había iniciado la discusión de una amplia reforma constitucional, que perfeccionaba el régimen de gobierno a través, por ejemplo, de una mayor regulación del actuar de las Cámaras (tales como clausura del debate) y de mayores facultades para el ejecutivo, tales como la regulación de las urgencias legislativas. ${ }^{43}$

Como es bien sabido, la intervención de los militares puso fin a la normalidad institucional, el Presidente Alessandri se ausentó del país con permiso del Congreso, el cual fue enseguida clausurado por aquéllos. Diferencias entre el alto mando y los oficiales insurrectos de menor graduación llevó a que, a comienzos de 1925, la oficialidad del ejército hiciera volver a Alessandri, quien retomaba el gobierno con apoyo militar $-\mathrm{y}$ popular $-\mathrm{y}$ con el Congreso clausurado. Es en este contexto

${ }^{40}$ Reproducida por Heise, Historia de Chile, 463-475.

${ }^{41}$ Gabriel Salazar, "Construcción de Estado en Chile: la Asamblea Constituyente de Asalariados e Intelectuales (1900-1925)", en Del poder constituyente de asalariados e intelectuales (Chile siglos XX y XXI) (Santiago: LOM, 2009). Sobre dicha asamblea constituyente, véase también Gonzalo Vial, Historia de Chile (1891-1973). Volumen III. Arturo Alessandri y los golpes militares (1920-1925) (Santiago: Editorial Santillana, 1987), 533.

${ }^{42}$ Una reseña del artículo de Gabriel Salazar en Paulo Recabal F., "Reflexión crítica en torno al artículo "Construcción de Estado en Chile: la Asamblea Constituyente de Asalariados e Intelectuales (1900-1925)" de Gabriel Salazar", en Seminario Estudios de la República, http://www.estudiosdelarepublica.cl/plugins/news/ images/8 paulo recabal reflexiun salazar pdf.pdf/

${ }^{43}$ Carrasco Delgado, Génesis y vigencia, 147; Heise, Historia de Chile, 451. 
que se produce el proceso constituyente que da origen a la Constitución de $1925 .{ }^{44}$

Los partidos de la Alianza Liberal, que habían acompañado a Alessandri durante todo su período, pidieron la reapertura del Congreso que los militares habían clausurado el año anterior; los partidos de la opositora Unión Nacional exigieron que se convocara a elecciones parlamentarias. A su vez, la oficialidad del ejército había hecho saber su voluntad de que se llamara a una asamblea constituyente, con participación en ella de "las fuerzas vivas", ${ }^{45}$ para crear una nueva constitución, a lo que se comprometió Alessandri. De modo que, permaneciendo el Congreso Nacional clausurado y sin que se llamara a elecciones parlamentarias, Alessandri optó por designar por decreto una Comisión Consultiva, de 122 integrantes, con participación de militares, ${ }^{46}$ para resolver sobre los procedimientos que permitieran organizar una asamblea nacional constituyente. El debate entre los comisionados llevó a que se crearan dos subcomisiones, una prepararía el proyecto de reforma, y la otra trataría sobre la forma como sería aprobada. La Subcomisión de Reforma estuvo integrada por quince personas directamente llamadas por Alessandri, quien la presidió. Esta instancia se reunió en 30 ocasiones, mientras que la otra subcomisión, que debía organizar la asamblea constituyente, se reunió sólo tres veces y no volvió a ser convocada por el Presidente. ${ }^{47}$

A mediados de 1925, el proyecto elaborado en la Subcomisión de Reforma pasó a la Comisión Consultiva, cuyas indicaciones volvieron a la Subcomisión para su discusión. Es que la mayoría de los miembros de la Comisión Consultiva, desde conservadores a comunistas pasando por sectores liberales y el conjunto de los radicales, estaba por preservar el régimen parlamentario introduciendo reformas a la Constitución en aras de su perfeccionamiento. En cambio, Arturo Alessandri y la oficialidad del ejército exigían la instauración de un régimen presidencial y

${ }^{44}$ Correa Sutil et. al., Historia del siglo XX, capítulo IV.

${ }^{45}$ Vial, Historia de Chile, 447, 532-534.

${ }^{46}$ Integraron la Comisión Consultiva el general Mariano Navarrete, inspector general del ejército, y el mayor Óscar Fenner, auditor general de guerra. Véase General Mariano Navarrete, Mi actuación en las revoluciones de 1924 y 1925. Edición y presentación de René Millar Carvacho (Santiago: Centro de Estudios Bicentenario, 2004), 296-299.

47 Carrasco Delgado, Génesis y vigencia, 149-153; Navarrete, Mi actuación, 296-315; Vial, Historia de Chile, capítulo 13. 
no estaban dispuestos a hacer concesiones al respecto. Para imponerlo fue necesaria la intervención directa de los militares, en la persona del general Navarrete, inspector general del ejército y miembro de la Comisión Consultiva. Particularmente relevante es el hecho de que en su intervención el general Navarrete invistiera a los militares de la condición de portadores de la soberanía popular, cuando exigió la aprobación del régimen presidencial en el seno de la Comisión, declarando: "Los dirigentes de los diversos partidos políticos en que está dividida la opinión pública, deben aprovechar en esta ocasión las múltiples lecciones objetivas que han recibido desde el 5 de Septiembre hasta hoy. De ellas deben deducir lo que el país quiere, como asimismo inclinarse respetuosos ante su voluntad soberana, pues de otro modo se tendrán a corto plazo que hacer, bajo la presión de la fuerza, las reformas que, en representación del pueblo, ha reclamado en forma tan significativa el elemento joven del Ejército." En consecuencia, la Comisión Consultiva aprobó el proyecto de la Subcomisión y se disolvió. ${ }^{48}$

El Presidente convocó a plebiscito para fines de agosto, con el propósito de aprobar el proyecto elaborado en la pequeña Subcomisión. En el referéndum se utilizaron tres votos de distinto color cuya redacción fue hecha por el mismo Alessandri. Quienes aprobaran el proyecto presidencial tendrían un voto color rojo que señalaba que éste era aquél "cuya aprobación pide el Presidente de la República"; el texto del voto disidente, de color azul, decía: "Se mantiene el régimen parlamentario con la facultad de la Cámara de Diputados para censurar y derribar Gabinetes y de aplazar el despacho y vigencia de las Leyes de Presupuestos y recursos del Estado"; un voto color blanco expresaba "el rechazo absoluto de todo proyecto o fórmula constitucional indicándose así la voluntad del sufragante en orden a recurrir a otro medios para resolver la normalidad constitucional". Además Alessandri se dirigió por radio al

${ }^{48}$ La cita corresponde a la sesión del 23 de julio de 1925 de la Comisión Consultiva de Reformas Constitucionales, en Ministerio del Interior, Actas oficiales de las sesiones celebradas por la Comisión y Subcomisión encargadas del estudio del Proyecto de Nueva Constitución Política de la República (Santiago: Imprenta Universitaria, 1926), 455. Con pequeñas diferencias de redacción se encuentra también en Navarrete, Mi actuación, 304, versión ésta que reproduce Carrasco Delgado, Génesis y vigencia, 154-155. A juicio de Gonzalo Vial, se había producido un tercer golpe de Estado, el del 23 de julio, que se sumaba al del 5 de septiembre de 1924 y del 23 de enero de 1925: Vial, Historia de Chile, 541-546. 
país solicitando la aprobación del proyecto de la Subcomisión de Reforma. Los partidos Conservador, Radical y una fracción del Partido Liberal llamaron a la abstención; el Partido Comunista llamó a votar por el voto disidente. ${ }^{49}$ De modo que tanto el haber diferenciado los votos por colores como el texto que contenía cada uno de éstos, más la intervención presidencial directa, da claras señales de una manipulación de la voluntad electoral. No ha de sorprender entonces que hubiese más de un 50 por ciento de abstención y que la opción presidencial fuese aprobada por casi un 95 por ciento de los sufragios, equivalente a menos de 130 mil votos, que corresponde a menos de la mitad de los votantes en la elección presidencial siguiente, de octubre de 1925. La nueva constitución fue promulgada el 18 de septiembre de $1925 .^{50}$

La vorágine de los acontecimientos políticos impidió que la Constitución entrara plenamente en vigencia sino hasta fines de diciembre de 1932. Es bien sabido que en 1925 Alessandri no pudo terminar su período de gobierno dado el poder desplegado por el coronel Ibáñez; que éste tomó el control del proceso político imponiendo una dictadura; que su renuncia forzada a mediados de 1931 llevó a un brevísimo gobierno civil que fue derrocado a mediados de 1932 por un golpe de Estado que instauró una República Socialista, la que fue también derrocada a fines del año. Durante dicha República Socialista, en su fase más dictatorial, se pretendió convocar a una asamblea constituyente para dictar una nueva constitución, de carácter socialista-corporativista. ${ }^{51}$ No fue aquella la única propuesta de esta índole pues, por ejemplo, ese mismo año 1932 el jesuita Fernando Vives daba a conocer un conjunto de ideas para una "Constitución Cristiana del Estado", de carácter corporativista, recogiendo en ella las nuevas corrientes del pensamiento socialcristiano de entreguerras. ${ }^{52}$ Los radicales, por su parte, en 1931 y nuevamente en

${ }^{49}$ Carrasco Delgado, Génesis y vigencia, 155-157.

${ }^{50}$ Federico Gil, El sistema político de Chile (Santiago: Editorial Andrés Be1lo, 1969), 108; Correa Sutil et. al., Historia del siglo XX, 101. Las cifras exactas pueden encontrarse en Sofía Correa Sutil et. al., Documentos del siglo XX chileno (Santiago: Sudamericana, 2001), 560.

${ }^{51}$ Correa Sutil et al., Historia del siglo XX, capítulo IV.

${ }^{52}$ Sofía Correa Sutil, "El pensamiento en Chile en el siglo XX bajo la sombra de Portales", en Ideas en el siglo. Intelectuales y cultura en el siglo XX latinoamericano, coordinado por Óscar Terán (Buenos Aires: Siglo XXI Editores Argentina y Fundación OSDE, 2004), 209-305, especialmente 251-265. 
1933, presentaron proyectos de reforma constitucional al Congreso para establecer un régimen parlamentario de gobierno. ${ }^{53}$

Sin embargo, el régimen presidencial se legitimó con el tiempo, y la Constitución de 1925 fue reformada en sólo seis ocasiones, dos de las cuales restringieron aún más las atribuciones del Congreso. En efecto, el ejecutivo promovió reformas que aumentaran sus facultades, argumentando que los partidos políticos se habrían constituido en una barrera para la eficacia gubernamental. ${ }^{54}$ Por ello ha sido usual entender las dificultades políticas, durante la vigencia de esta carta, como un producto de la nefasta tensión entre el Presidente y los partidos, especialmente el partido de gobierno. De una mayor complejidad es el análisis del constitucionalista Felipe Meléndez, quien argumenta que durante gran parte de la vigencia de la Constitución de 1925 - hasta mediados de los años 60 - los partidos políticos ejercieron en el Congreso prácticas parlamentarias de vieja data, las que permitieron equilibrar las fuertes atribuciones del ejecutivo. De este modo el autor desplaza el análisis desde los partidos hacia el Congreso Nacional y el equilibrio de poderes. ${ }^{55}$ Ello, a su vez, permite situarnos en el momento constituyente, cuando el régimen presidencial se impone por la férrea voluntad de Arturo Alessandri y de los militares, en contra de la opinión mayoritaria de los partidos políticos de la época, desde conservadores a comunistas, pasando por los radicales, probablemente los más parlamentaristas.

Por otra parte, contrariamente a lo que se suele sostener sobre la prescindencia política de las fuerzas armadas durante la vigencia de la Constitución de 1925, éstas estuvieron atentas a su desenvolvimiento desde los orígenes mismos de la carta, como hemos visto. De hecho, formaron parte del ejecutivo en diversas ocasiones, participando en

${ }^{53}$ Carrasco Delgado, Génesis y vigencia, 202 nota 411.

${ }^{54}$ Carrasco Delgado, ibídem, 183-187, 197.

${ }^{55}$ Felipe Meléndez Ávila, "El rol de los partidos políticos en la determinación de la forma de gobierno bajo la Constitución de 1925", en Seminario Estudios de la República, http://www.estudiosdelarepublica.cl/plugins/news/images/37_felipe melundez_el_rol_de_los_partidos_poluticos_bajo_la_constituciun_de_1925_pdf. pdf/. Véase también su tesis de licenciatura para obtener el grado de licenciado en ciencias jurídicas y sociales en la Facultad de Derecho de la Universidad de Chile, titulada El Congreso Nacional bajo la Constitución de 1925: la dinámica entre los partidos, las cámaras y la presidencia (2010). 
los gabinetes de Ríos, González Videla, Ibáñez y Allende, ${ }^{56}$ velando siempre por la permanencia del régimen presidencial que habían impuesto al país en 1925. Incluso más, desde 1941 se hace a los militares responsables de custodiar la corrección de los procesos electorales, por lo que toman el control de los locales de votación, y en general del país completo, antes, durante y después de las elecciones, lo que los transforma en lo que hoy llamaríamos garantes de la institucionalidad electoral. ${ }^{57}$

No obstante, con el correr del tiempo, la Constitución de 1925 gozó de legitimidad y prestigio ante la ciudadanía. No fue ajena a ello la implacable crítica al parlamentarismo oligárquico de fin de siglo que, hacia 1930, levantó la historiografía nacionalista de Alberto Edwards y Francisco Antonio Encina, así como también los nuevos partidos políticos de izquierda y los socialcristianos. La demonización del parlamentarismo como régimen de gobierno redundó en la legitimidad de la Constitución de $1925 .^{58}$ Además, hay que considerar que contribuyó a su legitimación el que de la mano de esta carta se extendió el derecho a sufragio y se perfeccionó el sistema electoral. En efecto, la Constitución de 1925 creó el Tribunal Calificador de Elecciones, una autoridad independiente que daba garantías de imparcialidad; suprimió el voto acumulativo reemplazándolo por un sistema de representación proporcional; y terminó con la elección indirecta del Presidente de la República. Adicionalmente, un paso muy significativo hacia la corrección del proceso de votación lo constituyó la reforma electoral de 1958, que creó un único voto impreso por el Estado, el que contenía el total de las candidaturas, la llamada cédula única, que puso término definitivamente a la práctica del cohecho, al imposibilitar el control del votante. Con el fin del cohecho se acabaron los tumultos que éste generaba; aun así, sin embargo, los militares continuaron custodiando los locales de vota-

${ }^{56}$ Carrasco Delgado, Génesis y vigencia, 217.

57 Véase http://www.senado.cl/elecciones-durante-el-siglo-xx-el-inicio-yconsolidacion-de-la-democracia-en-chile/prontus_senado/2013-11-08/163850. html\#vtxt_cuerpo_T7/ (última visita: 8 de diciembre de 2014).

58 Correa Sutil, "El pensamiento en Chile"; Correa Sutil, "El Congreso"; Joaquín Trujillo Silva, "La invención del parlamentarismo en Chile", en Democracia $y$ derechos fundamentales desde la filosofía politica. Tercer Congreso Estudiantil de Derecho y Teoría Constitucional, Facultad de Derecho Universidad de Chile, varios autores (Santiago: Editorial Jurídica, 2009). 
ción. ${ }^{59}$ En cuanto a la ampliación del sufragio, desde 1935 extranjeros y mujeres pudieron votar en elecciones municipales; las mujeres lograron ciudadanía plena en 1949 y votaron por primera vez en una elección presidencial en 1952 y en elecciones parlamentarias en 1953; en 1962 se exigió la inscripción obligatoria, lo que aumentó el número de inscritos; y con la reforma constitucional de 1970 el sufragio se amplió a los jóvenes desde los 18 años y a los analfabetos. ${ }^{60}$ De modo que si para la elección presidencial de 1946 votaron 479.310 personas, en 1970 la cantidad había aumentado a 2.954 .799 votantes. ${ }^{61}$

Y sin embargo, el golpe de Estado de 1973, con el que se inicia una larga y cruenta dictadura, es la demostración más patente del fracaso del régimen presidencial, impuesto por los militares y Alessandri en la Constitución de 1925, y de sus sucesivas reformas que buscaron constantemente mayores facultades para el Presidente de la República. Precisamente, durante la transición de la dictadura pinochetista a la democracia se produjo una intensa discusión académico-política sobre el régimen de gobierno que más convenía a Chile, generándose un cierto consenso en torno a la idea de instaurar un régimen semiparlamentario o semipresidencial. En todo caso, habría habido en ese entonces acuerdo en abandonar el presidencialismo que se impuso con la Constitución de 1925, al cual se responsabilizó de la crisis política que culminó en el golpe de Estado. ${ }^{62}$

59 Véase http://www.senado.cl/elecciones-durante-el-siglo-xx-el-inicio-yconsolidacion-de-la-democracia-en-chile/prontus_senado/2013-11-08/163850. html\#vtxt_cuerpo_T7/ (última visita, 8 de diciembre de 2014).

60 Véase http://www.senado.cl/elecciones-durante-el-siglo-xx-el-inicio-yconsolidacion-de-la-democracia-en-chile/prontus_senado/2013-11-08/163850. html\#vtxt_cuerpo_T7/ (última visita, 8 de diciembre de 2014).

${ }^{61}$ Correa Sutil et al., Documentos del siglo XX, 560-561.

62 Véase, por ejemplo, Genaro Arriagada, "El sistema político chileno (Una exploración del futuro)", Colección Estudios Cieplan 15, (1984), 171202, http://www.cieplan.org/media/publicaciones/archivos/117/Capitulo_4.pdf/; Humberto Nogueira Alcalá, El régimen semipresidencial. ¿Una nueva forma de gobierno democrática? (Santiago: Grupo de Estudios Constitucionales, 1984); Arturo Valenzuela, "Orígenes y características del sistema de partidos en Chile: Proposición para un gobierno parlamentario”, Estudios Públicos 18 (1985), 1-69, http://www.cepchile.cl/dms/archivo_1289_3048/rev18_AValenzuela.pdf/; Juan Linz y Arturo Valenzuela, "Mesa redonda. Presidencialismo, semipresidencialismo y parlamentarismo", Estudios Públicos 36 (1989), 5-70, http://www.cepchile. cl/dms/archivo_1055_2455/rev36_avalenzuela_jlinz.pdf/; Giovanni Sartori y otros, "Mesa redonda. Consideraciones sobre alternativas semipresidenciales y parlamentarias de gobierno", Estudios Públicos 42 (1991), 7-44, http:// www.cepchile.cl/dms/archivo_1045_1239/rev42_sartori.pdf/. También, Arturo 


\section{LA CONSTITUCIÓN DE 1980: DE LA ILEGITIMIDAD A UNA PRECARIA LEGITIMACIÓN}

El golpe de Estado de 1973 destruyó la institucionalidad y el orden constitucional; la Junta de Gobierno, que integraron los comandantes en jefe de las cuatro ramas de las fuerzas armadas, no sólo asumió el poder total sino que también derogó la Constitución de 1925 y se arrogó el poder constituyente. ${ }^{63} \mathrm{Si}$ el año 1925 los militares, en palabras del general Navarrete, se adjudicaron la representación del pueblo y por esa vía la potestad constituyente, a vista y paciencia de toda la dirigencia política, esta vez, directa y explícitamente, tomaron para sí el poder constituyente, sin que mediara referencia alguna al pueblo. En consecuencia, a pocos días del golpe de Estado, la Junta llamaba a un puñado de constitucionalistas (ocho civiles) encomendándoles la preparación de un nuevo texto constitucional. Tal fue la Comisión Constituyente, que pasó a llamarse posteriormente Comisión de Estudio de la Nueva Constitución Política de la República, la que funcionó desde el 24 de septiembre de 1973 hasta el 5 de octubre de 1978. ${ }^{64}$ Entre tanto, para que a nadie le cupiera duda alguna respecto de la nueva situación, la Junta de Gobierno ejercía su potestad constituyente dictando actas constitucionales.

En octubre de 1978, la Comisión le entregó a Pinochet el anteproyecto de una nueva constitución. En noviembre, el documento pasó al Consejo de Estado, órgano consultivo de 18 miembros, civiles y militares, designados por Pinochet, quienes elaboraron un nuevo texto constitucional, diferente al de la Comisión, más cercano a una reforma de la Constitución de 1925 que el que había preparado la Comisión

Valenzuela, "Partidos políticos y crisis presidencial en Chile: Proposición para un gobierno parlamentario", en Hacia una democracia moderna. La opción parlamentaria, editado por J. Juan Linz, Arend Lijphart, Arturo Valenzuela y Óscar Godoy Arcaya (Santiago: Ediciones Universidad Católica de Chile, 1990); Sofía Correa Sutil, "El Congreso".

${ }^{63}$ Ruiz-Tagle, "El constitucionalismo chileno", 128-131.

${ }^{64}$ Integraron la Comisión de Estudio Constitucional: Enrique Ortúzar, quien la presidía, Sergio Diez, Jaime Guzmán, Jorge Ovalle; el 9 de octubre se incorporaron Enrique Evans, Gustavo Lorca, Alejandro Silva Bascuñán; el 21 de diciembre, se designó a Alicia Romo. En marzo de 1977 renunciaron Alejandro Silva Bascuñán y Enrique Evans; en mayo, Jorge Ovalle; fueron reemplazados por Luz Bulnes, Raúl Bertelsen y Juan de Dios Carmona. Véase Carrasco Delgado, Génesis y vigencia, 222-225. 
de Estudio, y lo entregaron a la Junta de Gobierno en julio de $1980 .{ }^{65}$ Para definir entre ambos proyectos, ésta designó un grupo de trabajo de ocho personas, con sólo dos civiles integrándolo, los ministros de Interior y de Justicia. Este grupo despachó en un mes el texto definitivo de la nueva carta fundamental, diferente al que había sido enviado por el Consejo de Estado, y más cercano al proyecto de la Comisión de Estudio. ${ }^{66}$ Sin registros electorales, ni libertades públicas, ni garantías individuales, el nuevo texto constitucional fue plebiscitado en septiembre de 1980. Con sólo un 6 por ciento de abstención, se contabilizó un 66 por ciento de votos a favor de la nueva carta. ${ }^{67}$ Se trataba tan sólo de un mecanismo de ratificación de la decisión adoptada por la Junta de Gobierno, pues ésta no se desprendió en caso alguno del poder constituyente que se había arrogado para sí. De tal modo lo explicitaron, por lo demás, los profesores de la Facultad de Derecho de la Universidad Católica, quienes dejaron en claro que si no se aprobase el texto constitucional en el plebiscito "no perderá por ello la Honorable Junta de Gobierno el Poder constituyente originario". ${ }^{68}$ En marzo de 1981 entraba en vigencia el articulado transitorio de la nueva constitución.

Entretanto, opositores a la dictadura, incluyendo desde figuras del Partido Demócrata Cristiano al Partido Socialista, reunidos en el Grupo de Estudios Constitucionales o Grupo de los 24, intentaban formular y materializar una nueva carta fundamental, sin lograr éxito en este aspecto. ${ }^{69}$

${ }^{65}$ Carrasco Delgado, ibidem, 234-238; Sofía Correa Sutil y Pablo Ruiz-Tagle Vial, Ciudadanos en democracia. Fundamentos del sistema político chileno (Santiago: Debate Random House Mondadori, 2010), 129-132.

${ }^{66}$ Robert Barros, La Junta Militar. Pinochet y la Constitución de 1980 (Santiago: Sudamericana, 2005), capítulos 5 y 6. Robert Barros ha hecho notar que no existen actas de la deliberación sobre la Constitución por parte de la Junta Militar. Véase también Carrasco Delgado, Génesis y vigencia, 243-244; 251-254.

${ }^{67}$ Carrasco Delgado, ibidem, 255-259; Claudio Fuentes, El fraude. Crónica sobre el plebiscito de la Constitución de 1980 (Santiago: Hueders, 2013).

68 "Declaración de profesores de la Facultad de Derecho de la Pontificia Universidad Católica de Chile respecto de la convocatoria a plebiscito para ratificar la Constitución", citado en Correa Sutil et al., Historia del siglo XX, 326.

69 Véase Informe del Grupo de los 24, 1979, reproducido en http://www. archivochile.com/Partidos_burguesia/doc_gen/PBdocgen0013.pdf/. En la revista Mensaje de mayo de 1981 se hizo un resumen de las objeciones del Grupo de los 24 a la Constitución del 80: Felipe Adelmar, "La constitución autoritaria. Opinión del 'Grupo de los 24"', Mensaje 298, mayo 1981, http://biblioteca.uahurtado.cl/ujah/ msj/docs/1981/n298_171.pdf/ 
La nueva constitución nació deslegitimada desde el origen. Así lo hizo saber el ex Presidente de la República Eduardo Frei Montalva, en su discurso en el Teatro Caupolicán con ocasión del llamado a plebiscito que hacía la dictadura para aprobar la nueva constitución. Frente a toda la oposición presente, desde comunistas a democratacristianos, planteó Frei la ilegitimidad de origen de la nueva carta constitucional, la que - además - en cuanto a su contenido no tendría precedentes en la historia de Chile, ya que solamente buscaba la consolidación del poder de Pinochet y su prolongación hasta finales del siglo. ${ }^{70} \mathrm{En}$ aquella ocasión también habló el filósofo Jorge Millas, quien rechazó el articulado de la nueva carta e impugnó la validez del plebiscito con el que la Junta Militar pretendía legitimarla. "El problema de la nueva Constitución, dijo Jorge Millas en aquella ocasión, seguirá siendo la gran tarea histórica de los chilenos libres." ${ }^{\prime 71}$ El plebiscito, en las condiciones en que se lo estaba convocando, también fue rechazado por los obispos católicos, el Grupo de Estudios Constitucionales o de los 24, por figuras señeras de la sociedad chilena, incluso por organizaciones sindicales que habían logrado organizarse a pesar de la represión. ${ }^{72}$

Pero no fue sino hasta el triunfo del NO a Pinochet en el plebiscito de octubre de 1988 que se pudo poner en primera línea de discusión el tema constitucional. La Concertación de Partidos por la Democracia recién triunfante buscó acordar con uno de los partidos afines al régimen - Renovación Nacional - un conjunto de reformas constitucionales. El momento era particularmente apremiante, dado que aún regía el articulado transitorio de la carta del 80 , según el cual bastaba una consulta popular vía plebiscito para reformar la Constitución. En cambio,

70 Eduardo Frei M., "Discurso con motivo del plebiscito de 1980. Teatro Caupolicán, 27 de agosto de 1980", http://www.casamuseoeduardofrei.cl/site/wpcontent/uploads/2009/04/Discurso-con-motivo-del-Plebiscito-de-1980.pdf/ (última visita, 4 de enero de 2015). Frei propuso entonces un gobierno de transición que convocara al cabo de un par de años a una asamblea constituyente, entendiendo por tal un organismo electo por votación, representativo de todas las corrientes políticas, para que, decía Frei, tal como en 1925 redactara una nueva constitución, que como entonces se sometiera a plebiscito.

71 "Discurso de Jorge Millas en el Teatro Caupolicán, 27 de agosto de 1980". Reproducido en Fuentes, El fraude, 123-127 (la cita se encuentra en página 126).

${ }^{72}$ Frei M., Teatro Caupolicán. 
una vez que entrara en vigencia el articulado permanente, en marzo de 1990, se imposibilitaba de hecho reformarla, dado los exigentes requisitos para ello. ${ }^{73}$ La negociación entre los partidos de la Concertación y Renovación Nacional dio como fruto el acuerdo en un conjunto de reformas de la mayor relevancia, las cuales fueron propuestas al régimen a través del ministro del Interior. ${ }^{74}$ Algunas de éstas fueron rechazadas por el poder militar, pero 54 reformas fueron aceptadas y plebiscitadas en julio de 1989. Entre ellas cabe mencionar: la derogación del artículo que prohibía a los partidos marxistas; la modificación de los modos de reformar la Constitución, para hacerlo más expedito; el aumento de los senadores electos, disminuyendo de este modo el poder de los senadores designados y vitalicios que contemplaba la Constitución; y la integración del contralor en el Consejo de Seguridad Nacional, con lo cual éste quedaba compuesto por cuatro civiles además de los cuatro comandantes en jefe de las fuerzas armadas. También se limitaron algunas de las atribuciones de dicho Consejo, particularmente, la de representar (se modificó por dar su opinión) respecto de materias que pudiesen atentar contra las bases de la institucionalidad, y se limitó y precisó ante qué autoridades podría hacerlo. ${ }^{75}$

Un 86 por ciento de los votantes aprobó las reformas sometidas a plebiscito. Las fuerzas armadas continuaron tutelando la Constitución

${ }^{73}$ Mario Verdugo Marinkovic, "Modificaciones al procedimiento de reforma constitucional", en La reforma constitucional de 1989. Estudio crítico. Cuadernos de análisis jurídico 13 (enero de 1990), 77.

${ }^{74}$ El general Pinochet se habría negado a aceptar las reformas negociadas, provocando la renuncia del ministro de Interior y de otros tres ministros, más la del subsecretario de Interior. La postura del Almirante Merino proclive a aceptar las negociaciones, y probablemente también la de algunos generales, habría obligado a Pinochet a ceder en su intransigencia y a mantener a los ministros ya renunciados. Véase El Mercurio, "Cáceres revela sus horas más tensas como ministro", domingo 9 de noviembre de 2014, D13, nota periodística sobre el libro de Patricia Arancibia C., Carlos F. Cáceres. La transición a la democracia (Santiago: Ediciones LyD, 2014).

75 Francisco Cumplido, "Reformas al poder de seguridad", en La reforma constitucional de 1989. Estudio crítico. Cuadernos de análisis jurídico 13 (enero de 1990), 73-76; Claudio Fuentes, "Elites, opinión pública y cambio constitucional", en En nombre del pueblo. Debate sobre el cambio constitucional en Chile, editado por Claudio Fuentes (Santiago: Henrich Böll Stiftung y UDP, 2010), 55-56, 58, 6165. 
a través de diversas disposiciones, tales como la consagración constitucional de su calidad de garantes de la institucionalidad, a través de su presencia decisiva en el Consejo de Seguridad Nacional y en el Tribunal Constitucional, y con los cuatro comandantes en jefe de las distintas ramas de las fuerzas armadas instalados en el Senado. Tampoco se reformó el sistema electoral binominal, según el cual cada circunscripción elige dos candidatos y con un tercio de los votos la segunda minoría puede elegir uno de los dos parlamentarios. ${ }^{76}$

No pocos constitucionalistas han argumentado que la ratificación popular de las reformas le otorgó legitimidad a la carta fundamental. ${ }^{77}$ Ruiz-Tagle ha enfatizado que por medio de este acto electoral el poder constituyente volvió al pueblo, lo que hace que la Constitución, siendo materialmente la misma, sea formalmente otra, aunque conserve el sello neoliberal y autoritario de sus orígenes. ${ }^{78}$

Sin embargo, también se ha expresado una visión muy crítica del proceso de negociación en torno a las reformas constitucionales aprobadas en 1989. Tal es el caso del sociólogo Felipe Portales, quien ha afirmado que en esta negociación se habría generado un "pacto secreto" que llevó a que la Concertación aceptara modificar los artículos 65 y 68 que, de no haberse intervenido, le habrían otorgado al gobierno futuro de Patricio Aylwin la posibilidad de aprobar toda la legislación ordinaria, con mayoría absoluta en una Cámara y un tercio en la otra, reforma que habría pasado inadvertida en medio del conjunto plebiscitado en $1989 .{ }^{79}$

Por otra parte, a pesar de las reformas consensuadas y aprobadas por el plebiscito de 1989, muchas de las propuestas que la Concertación venía elaborando desde los tiempos del Grupo de los 24 habían quedado en el tintero. Por de pronto, la intensa discusión académico-política

${ }^{76}$ Correa Sutil y Ruiz-Tagle, Ciudadanos en democracia, 129-132; Correa Sutil et al., Historia del siglo XX, 336-339.

77 Pablo Ruiz-Tagle, "El constitucionalismo chileno", 130; Mario Verdugo Marinkovic, “¿Nueva constitución?”, Revista de Derecho Público (edición especial, marzo de 2014), 46.

${ }^{78}$ Pablo Ruiz-Tagle, ibídem, 130.

${ }^{79}$ Felipe Portales, Chile: una democracia tutelada, citado por Correa Sutil et al., Historia del siglo XX, 336-337. La misma idea respecto al artículo 68, pero con una connotación diferente, se replica en el citado "Cáceres revela sus horas más tensas como ministro". 
que se generó desde mediados de los años 80, involucrando a todos los sectores, con el propósito de alejarse del presidencialismo extremo de la constitución heredada, cayó en un mortal olvido con el inicio del primer gobierno de la Concertación. ${ }^{80}$ En efecto, a mediados de 1990 , recién inaugurado el gobierno de Patricio Aylwin, el poderoso titular del Ministerio Secretario General de la Presidencia, Edgardo Boeninger, encargó al jefe de la División Jurídico Legislativa de dicho ministerio que constituyera una comisión para proponer un proyecto de reformas constitucionales, pero, eso sí, con la limitación de no intervenir en la forma de gobierno presidencial que aseguraba la Carta del 80. De modo que se creó una comisión de cuatro constitucionalistas, quienes estudiaron los proyectos anteriores no contemplados en la reforma del 89, a saber: las materias que, habiendo sido consensuadas entre la Concertación y Renovación Nacional, no fueron incorporadas por los militares en el poder; las proposiciones del Grupo de Estudios Constitucionales conocido como Grupo de los 24; las bases programáticas de la Concertación, entre otras. ${ }^{81}$ Surgió de esta comisión una propuesta de reformas constitucionales que el ministro Boeninger desglosó de modo de enviar al Congreso unas reformas muy precisas y limitadas, referidas a temas de administración y del poder judicial. ${ }^{82}$ Este episodio demuestra la poca voluntad reformadora de los primeros gobiernos de la Concertación, explicable en la medida en que la concentración de poder en el ejecutivo los favorecía, y dado que el Senado continuaba siendo integrado por

80 Véase por ejemplo, Arriagada, "El sistema político chileno; Nogueira Alcalá, El régimen semipresidencial; A. Valenzuela, "Orígenes y características"; Linz y A. Valenzuela, "Presidencialismo, semipresidencialismo"; Sartori y otros, "Alternativas semipresidenciales"; A. Valenzuela, "Partidos políticos"; Correa Sutil, "El Congreso".

81 En 1986 la Concertación había establecido una Comisión de Reformas Constitucionales integrada por nueve constitucionalistas, los que centraron sus propuestas en seis puntos: mecanismo de reforma de la Constitución, composición y generación del Congreso, proscripción de los partidos marxistas, composición y "estructura" del Consejo de Seguridad Nacional, inamovilidad de los comandantes en jefe e incompatibilidad entre dirigente gremial y militante de partido político. Véase Fuentes, "Elites", 55-56, 58, 61-65.

${ }^{82}$ Carlos Andrade Geywitz, "Proyectos de reformas constitucionales en tramitación y estudio y comentarios de las proposiciones del Ministerio Secretaría General de la Presidencia de la República”, en Temas constitucionales. Cuadernos de análisis jurídico 20 (enero de 1992), 77-82. 
senadores designados, entre los cuales estaban los cuatro comandantes en jefe.

A pesar de lo pétrea que aparecía la Constitución de 1980, entre 1990 y 2003 se aprobaron numerosas leyes de reforma constitucional, aunque éstas no tocaron puntos medulares. ${ }^{83}$ De modo que no fue sino hasta 2005 que, a partir de un acuerdo de larga gestación entre la Concertación y la oposición de derecha, la Constitución de 1980 fue profundamente intervenida, al aprobarse 61 reformas, todas ellas sustantivas. Con respecto al Consejo de Seguridad Nacional, se cambió su composición sumando al presidente de la Cámara, lo que les dio mayoría a los civiles sobre los militares; se le quitó su injerencia en el nombramiento de los integrantes del Tribunal Constitucional, y se estableció que sólo podría ser convocado por el Presidente de la República, quedando como un ente asesor. Con respecto a las fuerzas armadas, se suprimió su condición de garantes de la institucionalidad, rol que se otorgó a todos los órganos del Estado, y se restituyó la facultad presidencial de llamar a retiro a los comandantes en jefe. Además, se eliminaron los senadores designados y vitalicios. Se fortaleció la facultad fiscalizadora de la Cámara de Diputados, al introducir en la Constitución la interpelación a los ministros de Estado. Se suprimió la distinción entre legislatura ordinaria y extraordinaria, dándole continuidad al trabajo legislativo. Se retiró de la Constitución la referencia al sistema electoral binominal, el que quedó inserto en la Ley Orgánica Constitucional sobre Votaciones Populares y Escrutinios. Se modificó la composición del Tribunal Constitucional; en las Bases Fundamentales se reconocieron los principios de probidad y transparencia; y se ahondó en materias de derechos fundamentales. ${ }^{84}$

Ciertamente la Constitución había cambiado, tanto así que el Presidente Ricardo Lagos estimó que había creado una nueva carta con estas reformas, una constitución definitivamente democrática, y le puso su firma al texto refundido, el cual promulgó el 17 de septiembre de 2005. Craso error político pues, a semanas de su promulgación, senadores de

${ }^{83}$ Carlos Carmona Santander, "Las reformas a la Constitución entre 1989 y 2013", Revista de Derecho Público (edición especial, marzo de 2014), 65-83.

84 Claudio Fuentes, El pacto. Poder, constitución y prácticas políticas en Chile (1990-2010) (Santiago: Ediciones Universidad Diego Portales, 2012); Fuentes, "Elites", 55-56, 58, 61-65, y del mismo libro y autor, "Prólogo", 9; Enrique Navarro Beltrán, "Reformas a la Constitución chilena", Revista de Derecho Público (edición especial, marzo de 2014), 19-20. 
la misma Concertación comenzaron a clamar por más reformas, por la derogación de varias leyes orgánicas constitucionales e incluso por una nueva constitución para el bicentenario de la República. ${ }^{85}$

Desde entonces se ha insistido en la precariedad de las reformas de 2005. Al respecto, por ejemplo, Ruiz-Tagle hace notar que se mantuvieron las fuertes atribuciones presidenciales, una concepción subjetiva de los derechos, que privilegia el derecho de propiedad y las libertades por sobre los derechos económicos y sociales; además, el sistema electoral mantiene la noción de democracia protegida y genera un déficit de representación democrática. Tampoco a su juicio estaría asegurada la subordinación del poder militar al poder civil, porque persiste la doctrina de la seguridad nacional y el Consejo de Seguridad Nacional. En suma, la Constitución permanecería igual "en sus rasgos dogmáticos principales y en sus principios neoliberales y autoritarios", de modo que sería la constitución "más deficitaria en cuanto a su carácter democrático." 86 Couso y Coddou, por su parte, también critican "el sesgo neoliberal de los derechos constitucionales", y "la legislación de súper mayoría", es decir, las leyes orgánico-constitucionales y las de quórum calificado que se combinan con el sistema electoral binominal y obligan a llegar a acuerdos con las fuerzas herederas de la dictadura. Critican también la "integración, designación y atribuciones del Tribunal Constitucional" con su capacidad de vetar la legislación y los actos administrativos en defensa del orden constitucional. ${ }^{87}$

De modo que, a pesar de la magnitud de las reformas aprobadas en 2005, éstas fueron de inmediato percibidas como insuficientes, lo que a nuestro juicio se debe a que no se reformó el sistema electoral binominal. En efecto, las reformas de 2005 sacaron de la Constitución el sistema electoral, el cual pasó a formar parte de la Ley Orgánica Constitucional sobre Votaciones Populares y Escrutinios, sin embargo, el sistema electoral binominal permaneció inalterable, limitando las posibilidades democratizadoras que abría la reforma constitucional de tulo 7.

${ }^{85}$ Fuentes, "Elites", 55-56, 58, 61-65 y, "Prólogo", 9; Fuentes, El pacto, capí-

${ }^{86}$ Ruiz-Tagle, "El constitucionalismo chileno", 131, 135, 137; Ruiz-Tagle, "La trampa del neopresidencialismo: la Constitución 'Gatopardo", capítulo 8 en $\mathrm{La}$ República en Chile, 198-200, 211-213.

${ }^{87}$ Javier Couso y Alberto Coddou, "Las asignaturas pendientes de la reforma constitucional chilena”, en Fuentes (ed.), En nombre del pueblo, 196-200. En la misma línea argumentativa se ha pronunciado también Fernando Atria. 
2005. El binominal — tan ligado a la "democracia protegida" que instaló la dictadura militar - ha producido efectos nefastos para la vida política, así como también ha sido dañino para todos los partidos, los que terminaron acomodándose y amoldándose a éste. ${ }^{88} \mathrm{Si}$ se le hubiese puesto fin, entonces la elección de un Congreso Nacional que reflejara todos los matices de expresión ciudadana habría podido profundizar la transformación de la Constitución, en materias tales como la definición de los derechos fundamentales, los altos quórum, y también, por qué no, podría haberse revitalizado el fructífero debate de principios de la década de los 90 sobre el régimen de gobierno, para así poder abandonar el presidencialismo centralizador que tanto ha complicado el desenvolvimiento político chileno durante casi todo el siglo XX a nuestros días. ${ }^{89}$ En otras palabras, habríamos tenido no uno sino varios congresos constituyentes, como sucedió en la década de 1870, produciendo una mutación constitucional como entonces.

\section{¿ASAMBLEA CONSTITUYENTE AHORA?}

La demanda por un cambio constitucional profundo ha estado asociada sobre todo desde 2013 a la convocatoria a una asamblea constituyente. Eso sí, hay que tener claro que ésta no es lo mismo que un Congreso constituyente. ¿Qué es entonces una asamblea constituyente?

No son muchos quienes precisan qué entienden por asamblea constituyente. Se habla sobre todo de participación de la ciudadanía, pero muy poco respecto a cómo se conformaría la asamblea. No obstante, en algunos casos se la ha definido con cierto detalle, y entonces la caracterización que han hecho de ella quienes la demandan con mayor ahínco no deja de ser sorprendente. Veamos.

88 Sofía Correa Sutil, “¿Representación corporativa en las sombras? Una reflexión histórica sobre las tendencias políticas del presente", en Anales de la Universidad de Chile Séptima Serie n. ${ }^{\circ} 2$ (2011), 67-76, http://www.anales.uchile.cl/ index.php/ANUC/article/viewFile/17299/20586/. Sobre las discusiones en torno al sistema binominal véase Fuentes, El pacto, capítulo 8.

89 Ruiz-Tagle habla del "presidencialismo ejecutivo", tomando el concepto de Bruce Ackerman, para caracterizar un fenómeno epocal que se despliega en América Latina y más allá. Ver "Democracia y constitucionalismo ejecutivo en Latinoamérica y Chile", ensayo V de El Constitucionalismo del miedo. Propiedad, bien común y poder constituyente, de Renato Cristi y Pablo Ruiz-Tagle (Santiago: LOM, 2014). 
Una corriente de pensamiento de izquierda radical encontró en la candidata presidencial de 2013 Roxana Miranda una posibilidad para amplificar sus voces. En efecto, Miranda situó como un punto central de su programa de gobierno la convocatoria a una "Asamblea Constituyente Social". Ésta consistiría en una organización a nivel nacional que debería recoger la deliberación que tendría lugar "en cada uno de los niveles de organización social y político-territorial, desde la junta de vecinos y otras organizaciones de base hasta el nivel nacional, pasando por la comuna, la región y el distrito.” La forma de operar debería ser de modo que: "Al concluir una fase, las unidades organizacionales definen a sus delegados y delegadas para que actúen de voceros y voceras en la deliberación que se producirá en el nivel político-territorial inmediatamente superior. Y así sucesivamente hasta la conformación de una gran Asamblea Constituyente Social de nivel nacional que se compone de voceros y voceras que han pasado por todo el proceso constituyente en cada nivel político territorial." De dicha deliberación a nivel nacional saldría el texto final de la nueva constitución, escrito "a mano y hasta con faltas de ortografía", el que "será sometido a aprobación por los pueblos de Chile a través de un referéndum vinculante." 90 Es decir, estamos ante una propuesta de democracia directa, fundada en núcleos de base populares desde donde, a través de voceros nunca de representantes, debería salir la nueva constitución, sin intermediaciones. Los sectores de izquierda radical $^{91}$ que portan esta propuesta de asamblea consideran inaceptable cualquier otra fórmula para crear una nueva constitución.

En líneas semejantes se ha expresado la ex presidenta de la FECh, hoy diputada por el Partido Comunista, Camila Vallejo, quien ha declarado que habría que hacer "muchas microasambleas constituyentes en nuestros barrios, en nuestros territorios." 92

${ }^{90}$ Roxana Miranda, “Asamblea Constituyente Social: Hacia una constitución hecha a mano y sin permiso", El Ciudadano, 16 de septiembre de 2013, http://roxanamiranda.cl/984/asamblea-constituyente-social-constitucion-hecha-mano/ (última visita, 16 de noviembre de 2014).

${ }^{91}$ Por ejemplo, Movimiento Nacional por una Asamblea Constituyente y Red de Estudiantes de Chile por la Asamblea Constituyente.

${ }^{92}$ El Mostrador, "Camila Vallejo: El pueblo tiene que estar preparado para un proceso constituyente", 2 de agosto de 2013, http://www.elmostrador.cl/ pais/2013/08/02/camila-vallejo-el-pueblo-tiene-que-estar-preparado-para-un-proceso-constituyente/\#print-compact/ (última visita 23 de noviembre de 2014). 
La organización Marca AC (marcaac2014@gmail.com) comparte con otras similares (con ONG Acción, por ejemplo) la idea expresada por Roxana Miranda de generar "poder social constituyente", y por tanto ni siquiera acepta que una nueva constitución pueda surgir de cabildos, como también algunos han propuesto. ${ }^{93}$ Veamos pues cómo conciben ellos una asamblea constituyente.

Auspiciada por Marca AC, se divulgó por correo electrónico y por internet una "Propuesta de composición y funcionamiento para una asamblea constituyente." En ella se diseña una asamblea de doscientos integrantes, quienes quedarían inhabilitados para postularse como candidatos a cualquier elección nacional, desde presidencial hasta municipal. De estos doscientos integrantes, se elegirían directamente sólo un poco más de la mitad, 110, los cuales podrán ser presentados a la elección por cualquier organización social o política; los candidatos podrán ser chilenos o extranjeros. Adicionalmente se sortearían cincuenta cupos, pero de ese sorteo se excluiría a los militantes de partidos políticos y a quienes tuviesen cargos de representación popular; veinte lugares en la asamblea constituyente estarían reservados a miembros del Congreso Nacional, los cuales deberían suspender sus actividades como congresistas mientras integrasen esta asamblea, la que deliberaría durante un año; el mismo número de escaños, veinte, estarían reservados para indígenas. En todos estos casos se aplicaría una cuota de género de un 40 por ciento. La asamblea en pleno deberá elegir una mesa directiva con tres presidentes, y funcionará en comisiones, e implementará instrumentos de democracia directa para asegurar la participación popular. La constitución que de allí resultase debería ser aprobada por mayoría absoluta de los asambleístas, en cada comisión y en el pleno, y luego debería ser ratificada en referéndum. Si el proyecto fuese rechazado, se convocaría a una nueva asamblea constituyente. ${ }^{94}$ Tal es la proposición de la organización Marca AC.

Como vemos, la asamblea constituyente va ligada indisolublemente a propuestas de democracia directa y representación sectorial o fun-

93 El Desconcierto, 10 de octubre de 2014, http://eldesconcierto.cl/marca-acmostro-preocupacion-por-la-posibilidad-de-que-cabildos-reemplacen-una-asamblea-constituyente/ (última visita, 8 de diciembre de 2014).

94 "Propuesta de composición y funcionamiento para una asamblea constituyente", en http://abelpinones.blogspot.com/ (última visita, 17 de noviembre de 2014). 
cional. Incluso, tal es el caso del manifiesto "Plebiscito para una nueva Constitución" suscrito inicialmente por 161 personalidades, incluyendo ex parlamentarios y ministros de Estado de los gobiernos de la Concertación, profesores universitarios, dirigentes sociales, e incluso un obispo de la Iglesia Católica. Allí, al proponerse una asamblea constituyente, se indica que ésta debe reflejar "representatividad social, cultural, regional, política, étnica y de género". 95

Es llamativo en las propuestas de asamblea constituyente la desconfianza y rechazo hacia la democracia representativa, y por tanto hacia sus instituciones nucleares como son el Congreso Nacional, espacio por excelencia para el acuerdo y la negociación política, y los partidos en cuanto canales de representación plural y articuladores de intereses divergentes. Tal es el caso evidente de la organización Marca AC, cuya propuesta hemos analizado. En efecto, si bien en ella aún se contempla la posibilidad de elección nacional de una proporción de los integrantes de la asamblea, cuestión que grupos más radicalizados rechazan vehementemente, no obstante considera la integración de miembros de la asamblea por sorteo, y otorga tantos cupos a parlamentarios activos como los que estarían "reservados" para indígenas, quienes tendrían de este modo un doble voto, como electores nacionales y como voto étnico. ¿Y por qué no podrían tener dos o tres votos el resto de los chilenos, así a secas? Al abrir la puerta a la representación sectorial, la demanda por "escaños reservados" necesariamente se ampliaría a los más diversos grupos funcionales y corporativos. Ya vemos que las mujeres tienen en esta propuesta una cuota de 40 por ciento de representación. ¿Y los jóvenes?, ¿los universitarios en particular?, ¿los profesores?, ¿los pobladores?, ¿los obreros?, ¿los sindicatos?, ¿los subcontratados de la minería del cobre?, ¿las regiones?, ¿los empresarios?, ¿los militares?, ¿el clero?, ¿los evangélicos?, etc., etc., etc. Así fue como le oí a un personaje con mucho sentido del humor preguntar si acaso él podría participar también en la asamblea constituyente en calidad de aristócrata de vieja cepa, pues tenía verdaderas ganas de integrarla.

De modo que en la propuesta de asamblea constituyente estamos ante un planteamiento corporativista, aunque de izquierdas. La repre-

95 Este manifiesto se puede encontrar en: http://issuu.com/nuevarepublica/ docs/manifiesto_plebiscito_para_una_nueva_constituci_n_/ (última visita, 23 de noviembre de 2014). 
sentación corporativa con democracia directa y mandato imperativo en reemplazo de la representación a través de partidos políticos constituye un camino hacia el caudillismo autoritario, en la medida en que se excluye la negociación política, que es la que permite construir entendimientos mirando a la totalidad social en una temporalidad más extensa que el presente inmediato. En las experiencias de representación corporativa son los grupos más fuertes los que se imponen sobre el conjunto social, a diferencia de la democracia representativa que implica la búsqueda del acuerdo político en espacios institucionales, particularmente en el Congreso Nacional. Por eso, el modelo corporativista entroniza al caudillo y pone fin al pluralismo político. ${ }^{96}$

En efecto, el corporativismo no ha sido ajeno a tradiciones de izquierda. Como hemos visto en este artículo, en las décadas de 1920 y 1930 hubo en Chile propuestas para la implantación de un corporativismo-socialista en un Estado funcional, con federalismo funcional, constituido desde la base social, sindical y de productores, desestimando la intermediación de los partidos políticos en la representación ciudadana. Para ello se propuso crear una constitución funcional, es decir, que asegurara la representación corporativa-sindical. Como es bien sabido, quienes portaban esta propuesta corporativista no tuvieron entonces la fuerza política para hacer prevalecer sus anhelos.

También fracasaron los partidos políticos, quienes en 1925 propusieron radicar en el Congreso Nacional un proceso constituyente que permitiera reformar significativamente la Constitución vigente. Contraponiendo la exigencia de una asamblea constituyente, se impuso, hemos visto, la decisión del ejército y del Presidente Alessandri. Por ello, la Constitución surgió de dos fuentes: de la discusión entre un puñado de hombres presididos por Alessandri, y de la venia del ejército. El plebiscito que consagró la Constitución presidencialista de 1925 no fue sino una imposición desde la fuerza ante una mayoría política que optó por abstenerse dadas las circunstancias. Si bien, en un comienzo, los partidos en el Congreso lograron neutralizar el fuerte presidencialismo, al final del período de vigencia de la Constitución de 1925 prevaleció la concentración de poder en el ejecutivo, hasta llevar el sistema político al quiebre institucional.

${ }^{96}$ Correa Sutil, “¿Representación corporativa?”. 
Hay quienes han planteado que hoy en día sería imposible tener una mutación constitucional vía reforma, negando de este modo la posibilidad de radicar el proceso constituyente en el Congreso Nacional. ${ }^{97}$ Quienes así argumentan, portan una visión inflexible de los procesos históricos y desconocen la historia constitucional chilena. Hemos analizado en este artículo cómo la Constitución de 1833 fue reformada tan profundamente en la década de 1870 que, produciéndose una mutación constitucional, esta carta, que concentraba el poder en el ejecutivo sin contrapesos, se convirtió en el sustento para un régimen de carácter parlamentario. La Constitución de 1833 hacía prácticamente imposible su reforma, dado el veto absoluto del Presidente, la necesidad de dos legislaturas para poder reformarla, y sobre todo dado el hecho de que el sistema electoral permitía al ejecutivo determinar la composición de ambas Cámaras. Ciertamente, un escenario mucho más cerrado que el de hoy. Y sin embargo, ya lo vimos, la Constitución fue reformada sustantivamente en conjunto con el sistema electoral.

Hemos argumentado, en este texto, que una reforma constitucional sustantiva es posible si va de la mano de una reforma electoral. Es decir, al reemplazarse el sistema electoral binominal por una fórmula de representación proporcional que dé cabida a las minorías partidistas, la composición del Congreso y la voluntad reformadora neutralizarían las exigencias de altos quórums necesarios para la reforma constitucional. Las mayorías parlamentarias podrían, en primer lugar, reformar la Constitución para suprimir dichos quórums y abrir así el proceso constituyente. Se ha objetado esta posibilidad argumentando que ninguna negociación política ha sido capaz de eliminar este núcleo inmovilizador. Sin embargo, a comienzos de 2012 las dirigencias de Renovación Nacional y de la Democracia Cristiana acordaron avanzar hacia nuevas reformas sustantivas de la Constitución, terminando con el binominal, descentralizando el poder político, y acercándose a un régimen de gobierno semipresidencial, entre otras significativas reformas. ${ }^{98}$ No deja

97 El más mediático de los exponentes de esta postura ha sido el abogado Fernando Atria, quien ha acuñado el slogan de "constitución tramposa" para argumentar la imposibilidad de una reforma sustantiva. Véase La constitución tramposa (Santiago: LOM, 2014).

${ }^{98}$ La Segunda, 18 de enero de 2012, http://www.lasegunda.com/Noticias/Politica/2012/01/714174/DC-y-RN-entregan-propuesta-de-reformas-politicas-Incluyefigura-de-un-primer-ministro/ (última visita, 8 de diciembre de 2014). 
de ser inquietante la secuencia y proximidad temporal: 2012, acuerdo RN-DC para terminar con el binominal y reformar la Constitución; 2013, arremetida por una asamblea constituyente, sí o sí, por la razón o la fuerza, "por las buenas o por las malas".

Ello no obstante, el fin del binominal ha sido aprobado (enero de 2015). El Congreso Nacional, portador de la representación democrática, podrá constituirse sin sombra de dudas en el asiento de los procesos constituyentes por venir.

\section{BIBLIOGRAFÍA CITADA}

Andrade Geywitz, Carlos. "Proyectos de reformas constitucionales en tramitación y estudio y comentarios de las proposiciones del Ministerio Secretaría General de la Presidencia de la República." Temas constitucionales. Cuadernos de Análisis Jurídico 20 (enero 1992): 77-111.

Arriagada, Genaro. "El sistema político chileno (Una exploración del futuro)." Colección Estudios Cieplan 15 (diciembre 1984): 171-202. http://www. cieplan.org/media/publicaciones/archivos/117/Capitulo_4.pdf/

Atria, Fernando. La constitución tramposa. Santiago: LOM, 2014.

Barros, Robert. La Junta Militar. Pinochet y la Constitución de 1980. Santiago: Sudamericana, 2005.

Bauer, Arnold. La sociedad rural chilena. Desde la conquista española a nuestros dias. Santiago: Editorial Andrés Bello, 1994.

Bengoa, José. Historia social de la agricultura chilena. Tomo I: El poder y la subordinación. Acerca del origen rural del poder y la subordinación en Chile. Santiago: Ediciones Sur, 1988.

- Historia social de la agricultura chilena. Tomo II: Haciendas y campesinos. Santiago: Ediciones Sur, 1990.

Bernaschina, Mario. “Génesis de la Constitución de 1925." Anales de la Facultad de Ciencias Jurídicas y Sociales III 5 (1957).

Campos Harriet, Fernando. Historia constitucional de Chile. Santiago: Editorial Jurídica de Chile, 1983.

Carmona Santander, Carlos. "Las reformas a la Constitución entre 1989 y 2013." Revista de Derecho Público (edición especial marzo 2014): 59-83.

Carrasco Delgado, Sergio. Génesis y vigencia de los textos constitucionales chilenos. Santiago: Editorial Jurídica de Chile, 2002.

Correa Sutil, Sofía. "El Congreso durante el parlamentarismo. Revisión crítica del centralismo presidencial." Hemiciclo Revista de Estudios Parlamentarios 4 (primer semestre de 2011): 155-172. Academia Parlamentaria de la Cámara de Diputados. http://www.academiaparlamentaria.cl/Hemiciclo/revistahemiciclo_ N4.pdf/ 
. "El pensamiento en Chile en el siglo XX bajo la sombra de Portales." En Ideas en el siglo. Intelectuales y cultura en el siglo XX latinoamericano, coordinado por Óscar Terán, 209-305. Buenos Aires: Siglo Veintiuno Editores Argentina y Fundación OSDE, 2004.

—_ “Representación corporativa en las sombras? Una reflexión histórica sobre las tendencias políticas del presente." Anales de la Universidad de Chile Séptima Serie 2 (2011): 67-76. http://www.anales.uchile.cl/index.php/ANUC/ article/viewFile/17299/20586/

Correa Sutil, Sofía, Consuelo Figueroa Garavagno, Alfredo Jocelyn-Holt Letelier, Claudio Rolle Cruz \& Manuel Vicuña Urrutia. Historia del siglo XX chileno. Balance paradojal. Santiago: Sudamericana, 2001.

- Documentos del siglo XX. Santiago: Sudamericana, 2001.

Correa Sutil, Sofía \& Pablo Ruiz-Tagle Vial. Ciudadanos en democracia. Fundamentos del sistema político chileno. Santiago: Debate Random House Mondadori, 2010.

Couso, Javier \& Alberto Coddou. "Las asignaturas pendientes de la reforma constitucional chilena." En En nombre del pueblo. Debate sobre el cambio constitucional en Chile, editado por Claudio Fuentes. Santiago: Henrich Böll Stiftung y UDP, 2010.

Cristi, Renato \& Pablo Ruiz-Tagle. El constitucionalismo del miedo. Propiedad, bien común y poder constituyente. Santiago: LOM, 2014.

—. La República en Chile. Teoría y práctica del constitucionalismo republicano. Santiago: LOM, 2006.

Cumplido, Francisco. "Reformas al poder de seguridad." En La reforma constitucional de 1989. Estudio crítico. Cuadernos de Análisis Jurídico 13 (enero de 1990): 73-76.

Donoso, Ricardo. Las ideas políticas en Chile. Buenos Aires: Eudeba, 1975.

Drake, Paul. Between tyranny and anarchy. A history of democracy in Latin America, 1800-2006. Stanford: Stanford University Press, 2009.

Fuentes, Claudio. "Elites, opinión pública y cambio constitucional." En En nombre del pueblo. Debate sobre el cambio constitucional en Chile, editado por Claudio Fuentes. Santiago: Henrich Böll Stiftung y UDP, 2010.

- El fraude. Crónica sobre el plebiscito de la Constitución de 1980. Santiago: Hueders, 2013.

— - editor. En nombre del pueblo. Debate sobre el cambio constitucional en Chile. Santiago: Henrich Böll Stiftung y UDP, 2010.

- El pacto. Poder, constitución y prácticas politicas en Chile (1990-2010). Santiago: Ediciones Universidad Diego Portales, 2012.

Gil, Federico. El sistema politico de Chile. Santiago: Editorial Andrés Bello, 1969.

Góngora, Mario. Ensayo histórico sobre la noción de Estado en Chile en los siglos XIX y XX. Santiago: Editorial Universitaria, 1986.

Heise G., Julio. Años de formación y aprendizaje políticos 1810-1833. Santiago: Editorial Universitaria, 1978. 
Historia de Chile. El período parlamentario 1861-1925. Tomo I. Fundamentos histórico-culturales del parlamentarismo chileno. Santiago: Editorial Andrés Bello, 1974.

—. El periodo parlamentario 1861-1925. Tomo II. Democracia y gobierno representativo en el periodo parlamentario. Santiago: Editorial Universitaria, 1982.

Jocelyn-Holt Letelier, Alfredo. La independencia de Chile. Tradición, modernización y mito. Santiago: Debolsillo, 2009.

. "El Liberalismo moderado chileno. Siglo XIX." Estudios Públicos 69 (1998): 439-485. http://www.cepchile.cl/dms/archivo_902_313/rev69 jocelynholt.pdf/

Joignant R., Alfredo. "El lugar del voto. La ley electoral de 1874 y la invención del ciudadano-elector en Chile.” Estudios Públicos 81 (2001): 245-275. http:// www.cepchile.cl/dms/archivo_1115_875/rev81_joignant.pdf/

Linz, Juan \& Arturo Valenzuela. "Mesa redonda. Presidencialismo, semipresidencialismo y parlamentarismo.” Estudios Públicos 36 (1989): 5-70. http://www.cepchile.cl/dms/archivo_1055_2455/rev36_avalenzuela_jlinz.pdf/

Linz, Juan J., Arend Lijphart, Arturo Valenzuela \& Óscar Godoy Arcaya (editores). Hacia una democracia moderna. La opción parlamentaria. Santiago: Ediciones Universidad Católica de Chile, 1990.

Meléndez Ávila, Felipe. "El rol de los partidos políticos en la determinación de la forma de gobierno bajo la Constitución de 1925". Seminario Estudios de la República. http://www.estudiosdelarepublica.cl/plugins/news/images/37 felipe_melundez_el_rol_de_los_partidos_poluticos_bajo_la_constituciun_ de_1925_pdf.pdf/

Navarro Beltrán, Enrique. "Reformas a la Constitución chilena." Revista de Derecho Público (edición especial marzo 2014): 15-25.

Nogueira Alcalá, Humberto. El régimen semipresidencial. ¿Una nueva forma de gobierno democrática? Santiago: Grupo de Estudios Constitucionales, 1984.

Palma González, Eric Eduardo. Historia del derecho chileno (1808-1924). Facultad de Derecho Universidad de Chile, sin fecha.

Recabal, Paulo. "Para entender la realidad electoral en los albores de la República: ciudadanía y representación en el primer Congreso Nacional." Seminario Estudios de la República. http://www.estudiosdelarepublica.cl/plugins/news/ images/17_paulo_recabal congreso_pdf.pdf/

- "Reflexión crítica en torno al artículo 'Construcción de Estado en Chile: la Asamblea Constituyente de Asalariados e Intelectuales (1900-1925)' de Gabriel Salazar". Seminario Estudios de la República. http://www. estudiosdelarepublica.cl/plugins/news/images/8_paulo_recabal__reflexiun_ salazar_pdf.pdf/

Ruiz-Tagle, Pablo. "El constitucionalismo chileno: entre el autoritarismo y la democracia". En La República en Chile. Teoría y práctica del constitucionalismo republicano, de Renato Cristi y Pablo Ruiz-Tagle. Santiago: LOM, 2006. 
—_. "La trampa del neopresidencialismo: la Constitución "Gatopardo"”. En La República en Chile. Teoría y práctica del constitucionalismo republicano, de Renato Cristi y Pablo Ruiz-Tagle. Santiago: LOM, 2006.

- "Democracia y constitucionalismo ejecutivo en Latinoamérica y Chile." En El constitucionalismo del miedo. Propiedad, bien común y poder constituyente, de Renato Cristi y Pablo Ruiz-Tagle. Santiago: LOM, 2014.

Salazar, Gabriel. Del poder constituyente de asalariados e intelectuales (Chile siglos XX y XXI). Santiago: LOM, 2009.

Sartori, Giovanni (expositor), Enrique Barros (moderador), Raúl Bertelsen, Bernardino Bravo, Arend Lijphart, Santiago Niño, Humberto Nogueira \& Arturo Valenzuela. "Mesa redonda. Consideraciones sobre alternativas semipresidenciales y parlamentarias de gobierno." Estudios Públicos 42 (1991): 7-44. http://www.cepchile.cl/dms/archivo_1045_1239/rev42_sartori. pdf/

Senado de la República de Chile. http://www.senado.cl/elecciones-durante-elsiglo-xx-el-inicio-y-consolidacion-de-la-democracia-en-chile/prontus senado/2013-11-08/163850.html\#vtxt_cuerpo_T7/

Trujillo Silva, Joaquín. "La invención del parlamentarismo en Chile." En Democracia y derechos fundamentales desde la filosofía política. Tercer Congreso Estudiantil de Derecho y Teoría Constitucional. Facultad de Derecho Universidad de Chile. Santiago: Editorial Jurídica, 2009.

Urzúa Valenzuela, Germán. Historia política de Chile y su evolución electoral (desde 1810 a 1992). Santiago: Editorial Jurídica de Chile, 1992.

Valenzuela, Arturo. "Orígenes y características del sistema de partidos en Chile: Proposición para un gobierno parlamentario.” Estudios Públicos 18 (1985): 1-69. http://www.cepchile.cl/dms/archivo_1289_3048/rev18_AValenzuela.pdf/

—. "Partidos políticos y crisis presidencial en Chile: Proposición para un gobierno parlamentario". En Hacia una democracia moderna. La opción parlamentaria, editado por J. Juan Linz, Arend Lijphart, Arturo Valenzuela y Óscar Godoy Arcaya. Santiago: Ediciones Universidad Católica de Chile, 1990.

Valenzuela, J. Samuel. Democratización vía reforma: La expansión del sufragio en Chile. Buenos Aires: Ediciones del IDES, 1985.

— . "Hacia la formación de instituciones democráticas: prácticas electorales en Chile durante el siglo XIX.” Estudios Públicos 66 (1997): 215-257. http:// www.cepchile.cl/dms/archivo_1158_697/rev66_valenzuela.pdf/

—. "La ley electoral de 1890 y la democratización del régimen político chileno.” Estudios Públicos 71 (1998): 265-296. http://www.cepchile.cl/dms/ archivo_1152_730/rev71_valenzuela.pdf/

Verdugo Marinkovic, Mario. "Modificaciones al procedimiento de reforma constitucional." En La reforma constitucional de 1989. Estudio crítico. Cuadernos de Análisis Jurídico 13 (enero de 1990): 77-81.

—_. “Nueva constitución?” Revista de Derecho Público (edición especial marzo de 2014): 45-49. 
Vial, Gonzalo. Historia de Chile (1891-1973). Volumen III. Arturo Alessandri y los golpes militares (1920-1925). Santiago: Editorial Santillana, 1987.

\section{Fuentes primarias}

Adelmar, Felipe. "La constitución autoritaria. Opinión del 'Grupo de los 24'." Mensaje 298, mayo de 1981. http://biblioteca.uahurtado.cl/ujah/msj/ docs/1981/n298_171.pdf/

Anuario estadístico de la República de Chile correspondiente a los años 18701871.

Anuario estadístico de la República de Chile correspondiente a los años 18771878.

"Discurso de Jorge Millas en el Teatro Caupolicán, 27 de agosto de 1980." Reproducido en El fraude. Crónica sobre el plebiscito de la Constitución de 1980, de Claudio Fuentes. Santiago: Editorial Hueders, 2013.

"Elecciones presidenciales, plebiscitos y consultas 1925-2000." En Documentos del siglo XX chileno, de Sofía Correa Sutil, Consuelo Figueroa Garavagno, Alfredo Jocelyn-Holt Letelier, Claudio Rolle Cruz y Manuel Vicuña Urrutia. Santiago: Sudamericana, 2001.

El Desconcierto, 10 de octubre de 2014. http://eldesconcierto.cl/marca-ac-mostropreocupacion-por-la-posibilidad-de-que-cabildos-reemplacen-una-asambleaconstituyente/ (última visita, 8 de diciembre de 2014).

El Mostrador. "Camila Vallejo: El pueblo tiene que estar preparado para un proceso constituyente". 2 de agosto de 2013. http://www.elmostrador.cl/ pais/2013/08/02/camila-vallejo-el-pueblo-tiene-que-estar-preparado-paraun-proceso-constituyente/\#print-compact/ (última visita 23 de noviembre de 2014).

Frei M., Eduardo. "Discurso con motivo del plebiscito de 1980. Teatro Caupolicán, 27 de agosto de 1980." http://www.casamuseoeduardofrei.cl/site/wp-content/ uploads/2009/04/Discurso-con-motivo-del-Plebiscito-de-1980.pdf/

Informe del Grupo de los 24. 1979. Reproducido en http://www.archivochile.com/ Partidos_burguesia/doc_gen/PBdocgen0013.pdf/

La Segunda, 18 de enero de 2012. http://www.lasegunda.com/Noticias/ Politica/2012/01/714174/DC-y-RN-entregan-propuesta-de-reformas-politicasIncluye-figura-de-un-primer-ministro/ (última visita, 8 de diciembre de 2014).

“Manifiesto. Plebiscito para una nueva constitución". http://issuu.com/ nuevarepublica/docs/manifiesto_plebiscito_para_una_nueva_constituci_n_/ (última visita, 23 de noviembre de 2014).

Ministerio del Interior. "Actas oficiales de las sesiones celebradas por la Comisión y Subcomisión encargadas del estudio del Proyecto de Nueva Constitución Política de la República”. 1926.

Miranda, Roxana. "Asamblea Constituyente Social: Hacia una constitución hecha a mano y sin permiso." El Ciudadano, 16 de septiembre de 2013. http:// 
roxanamiranda.cl/984/asamblea-constituyente-social-constitucion-hechamano/ (última visita, 16 de noviembre de 2014).

Navarrete, General Mariano. Mi actuación en las revoluciones de 1924 y 1925. Edición y presentación de René Millar Carvacho. Santiago: Centro de Estudios Bicentenario, 2004.

"Propuesta de composición y funcionamiento para una asamblea constituyente". Marca AC. http://abelpinones.blogspot.com/ (última visita, 17 de noviembre de 2014).

“Reglamento electoral de 1833.” Disponible en Seminario Estudios de la República. http://www.estudiosdelarepublica.cl/plugins/news/images/7_paulo_recabal presentaciun_reglamento_electoral_de_1833_pdf.pdf/

Valencia Avaria, Luis (compilador). Anales de la República. Tomos I y II actualizados. Santiago: Editorial Andrés Bello, 1986. EP 